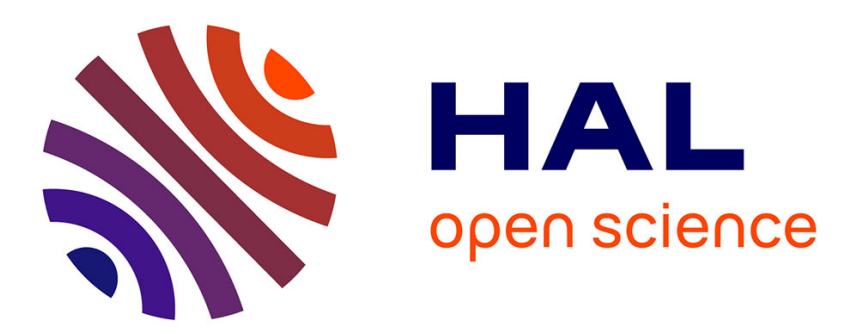

\title{
Changing controls on oceanic radiocarbon: New insights on shallow-to-deep ocean exchange and anthropogenic CO2 uptake
}

\author{
H. D. Graven, N. Gruber, R. Key, S. Khatiwala, Xavier Giraud
}

\section{To cite this version:}

H. D. Graven, N. Gruber, R. Key, S. Khatiwala, Xavier Giraud. Changing controls on oceanic radiocarbon: New insights on shallow-to-deep ocean exchange and anthropogenic CO2 uptake. Journal of Geophysical Research. Oceans, 2012, 117, pp.C10005. 10.1029/2012JC008074 . hal-00765149

HAL Id: hal-00765149

https://hal.science/hal-00765149

Submitted on 4 Jan 2022

HAL is a multi-disciplinary open access archive for the deposit and dissemination of scientific research documents, whether they are published or not. The documents may come from teaching and research institutions in France or abroad, or from public or private research centers.
L'archive ouverte pluridisciplinaire HAL, est destinée au dépôt et à la diffusion de documents scientifiques de niveau recherche, publiés ou non, émanant des établissements d'enseignement et de recherche français ou étrangers, des laboratoires publics ou privés. 


\title{
Changing controls on oceanic radiocarbon: New insights on shallow-to-deep ocean exchange and anthropogenic $\mathrm{CO}_{2}$ uptake
}

\author{
H. D. Graven, ${ }^{1,2}$ N. Gruber, ${ }^{1}$ R. Key, ${ }^{3}$ S. Khatiwala, ${ }^{4}$ and X. Giraud ${ }^{5}$ \\ Received 20 March 2012; revised 5 July 2012; accepted 22 August 2012; published 4 October 2012.
}

[1] The injection of radiocarbon $\left({ }^{14} \mathrm{C}\right)$ into the atmosphere by nuclear weapons testing in the 1950s and 1960s has provided a powerful tracer to investigate ocean physical and chemical processes. While the oceanic uptake of bomb-derived ${ }^{14} \mathrm{C}$ was primarily controlled by air-sea exchange in the early decades after the bomb spike, we demonstrate that changes in oceanic ${ }^{14} \mathrm{C}$ are now primarily controlled by shallow-to-deep ocean exchange, i.e., the same mechanism that governs anthropogenic $\mathrm{CO}_{2}$ uptake. This is a result of accumulated bomb ${ }^{14} \mathrm{C}$ uptake that has rapidly decreased the air-sea gradient of ${ }^{14} \mathrm{C} / \mathrm{C}\left(\Delta^{14} \mathrm{C}\right)$ and shifted the main reservoir of bomb ${ }^{14} \mathrm{C}$ from the atmosphere to the upper ocean. The air-sea $\Delta^{14} \mathrm{C}$ gradient, reduced further by fossil fuel dilution, is now weaker than before weapons testing in most regions. Oceanic ${ }^{14} \mathrm{C}$, and particularly its temporal change, can now be used to study the oceanic uptake of anthropogenic $\mathrm{CO}_{2}$. We examine observed changes in oceanic $\Delta^{14} \mathrm{C}$ between the WOCE/SAVE (1988-1995) and the CLIVAR (2001-2007) eras and simulations with two ocean general circulation models, the Community Climate System Model (CCSM) and the Estimating the Circulation and Climate of the Ocean Model (ECCO). Observed oceanic $\Delta^{14} \mathrm{C}$ and its changes between the 1980s-90s and 2000s indicate that shallow-to-deep exchange is too efficient in ECCO and too sluggish in CCSM. These findings suggest that mean global oceanic uptake of anthropogenic $\mathrm{CO}_{2}$ between 1990 and 2007 is bounded by the ECCO-based estimate of $2.3 \mathrm{Pg} \mathrm{C} \mathrm{yr}^{-1}$ and the CCSM-based estimate of $1.7 \mathrm{Pg} \mathrm{C} \mathrm{yr}^{-1}$.

Citation: Graven, H. D., N. Gruber, R. Key, S. Khatiwala, and X. Giraud (2012), Changing controls on oceanic radiocarbon: New insights on shallow-to-deep ocean exchange and anthropogenic $\mathrm{CO}_{2}$ uptake, J. Geophys. Res., 117, C10005, doi:10.1029/2012JC008074.

\section{Introduction}

[2] The observation and numerical simulation of anthropogenic transient tracers such as radiocarbon $\left({ }^{14} \mathrm{C}\right)$ and chlorofluorocarbons (CFCs) in the ocean provides a means for assessing the rates and spatial distribution of oceanic exchange with the atmosphere and the ocean circulation processes that regulate oceanic uptake and storage of anthropogenic $\mathrm{CO}_{2}$. Since ${ }^{14} \mathrm{C} / \mathrm{C}$ ratios (commonly expressed as $\Delta^{14} \mathrm{C}$, i.e., the

\footnotetext{
${ }^{1}$ Institute of Biogeochemistry and Pollutant Dynamics, ETH Zurich, Zurich, Switzerland.

${ }^{2}$ Scripps Institution of Oceanography, University of California, San Diego, La Jolla, California, USA.

${ }^{3}$ Program in Atmospheric and Oceanic Sciences, Princeton University, Princeton, New Jersey, USA.

${ }^{4}$ Lamont-Doherty Earth Observatory, Earth Institute at Columbia University, Palisades, New York, USA.

${ }^{5}$ CEREGE, UM34, Aix-Marseille University, Aix-en-Provence, France.

Corresponding author: H. D. Graven, Scripps Institution of Oceanography, University of California, San Diego, 9500 Gilman Dr., MC 0244, La Jolla, CA 92093-0244, USA. (hgraven@ucsd.edu)

C2012. American Geophysical Union. All Rights Reserved. 0148-0227/12/2012JC008074
}

deviation from an atmospheric standard and corrected for fractionation) have a very different atmospheric history and air-sea equilibration rate, anthropogenic ${ }^{14} \mathrm{C}$ has so far been regarded to have different processes controlling its global oceanic uptake from the atmosphere, compared to anthropogenic $\mathrm{CO}_{2}$ and CFCs [e.g., Toggweiler et al., 1989b; Sarmiento et al., 1992; Ito et al., 2004].

[3] Nuclear weapons testing added a large pulse of ${ }^{14} \mathrm{C}$ to the atmosphere in the 1950s and 60s [Rafter and Fergusson, 1957; Nydal, 1963]. Due to the strong air-sea gradients of $\Delta^{14} \mathrm{C}$ and the relatively long isotopic equilibration time for $\mathrm{CO}_{2}$ of about a decade [Broecker and Peng, 1974], the invasion of bomb-derived ${ }^{14} \mathrm{C}$ to the ocean during the subsequent decades was determined largely by the rate of air-sea gas exchange [Oeschger et al., 1975; Siegenthaler, 1983; Toggweiler et al., 1989b; Sarmiento et al., 1992]. This opened an opportunity to use the bomb ${ }^{14} \mathrm{C}$ signal to estimate the global mean gas exchange velocity [Broecker and Peng, 1982]. Such estimates have been made by employing oceanic circulation models and oceanic observations of $\Delta^{14} \mathrm{C}$ [Wanninkhof, 1992; Krakauer et al., 2006; Sweeney et al., 2007; Müller et al., 2008] after separating $\Delta^{14} \mathrm{C}$ into "natural" and "bomb" components using various methods [Broecker 

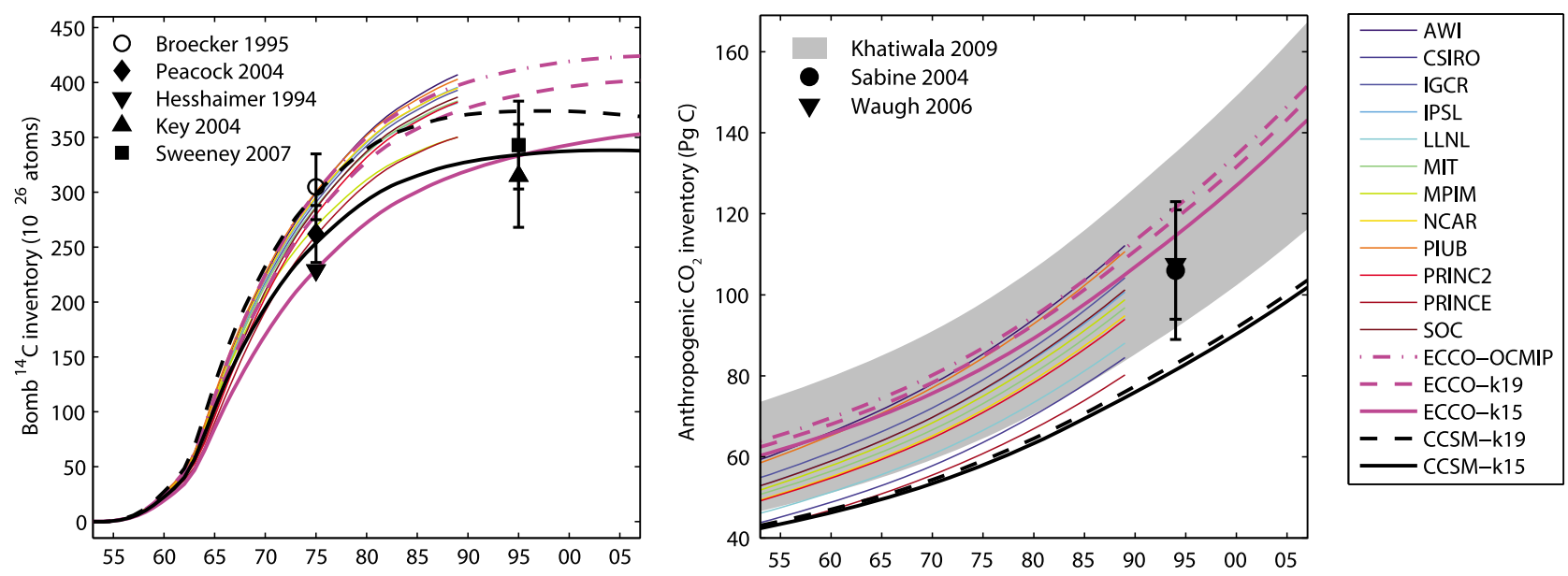

Figure 1. Oceanic inventories of bomb-derived ${ }^{14} \mathrm{C}$ (left) and anthropogenic $\mathrm{CO}_{2}$ (right) in models and observations. OCMIP-2 results are included only until 1989 since the atmospheric composition used for 1990-99 was substantially different than observed over the same period. The University of Liege and the Nansen Env. and Remote Sensing Center models are omitted due to model errors or a non-equilibrium initial state. Arctic and marginal ocean regions not included in GLODAP were omitted from model inventories of anthropogenic $\mathrm{CO}_{2}$. These regions were not omitted for bomb-derived ${ }^{14} \mathrm{C}$ inventories, but it should be noted that one data-based estimate [Key et al., 2004] is lower due to their exclusion.

et al., 1995; Rubin and Key, 2002; Peacock, 2004], or by balancing the budget of bomb-derived ${ }^{14} \mathrm{C}$ using atmospheric observations and carbon cycle models [Hesshaimer et al., 1994; Naegler et al., 2006].

[4] In contrast to the ${ }^{14} \mathrm{C}$ pulse, atmospheric $\mathrm{CO}_{2}$ grew steadily from its preindustrial $(\sim 1750)$ value to the present [Neftel et al., 1985; Keeling and Whorf, 2005]. The gradual accumulation and the roughly 10 times faster equilibration rate for $\mathrm{CO}_{2}$, compared to that of its isotopic ratio, causes the oceanic uptake of anthropogenic $\mathrm{CO}_{2}$ to be determined mainly by the rates of transport and mixing between shallow and deep ocean regions [Broecker and Peng, 1974; Oeschger et al., 1975; Siegenthaler, 1983; Sarmiento et al., 1992].

[5] The same processes also govern the uptake of CFCs, permitting scientists to use CFCs as analogs for anthropogenic $\mathrm{CO}_{2}$. $\mathrm{CFC}$ measurements have been used to estimate the penetration of anthropogenic $\mathrm{CO}_{2}$ or to estimate model skill by comparing modeled and observed CFC distributions [e.g., Sabine et al., 2004; Matsumoto et al., 2004; Mikaloff Fletcher et al., 2006; Khatiwala et al., 2009]. Ocean models vary substantially in their CFC uptake as a result of differences in transport and mixing between shallow and deep regions, and because of differences in their temperature distributions [Dutay et al., 2002; Matsumoto et al., 2004]. While CFC observations have been extremely useful in identifying timescales of ocean circulation and model deficiencies [e.g., Doney and Hecht, 2002], additional metrics are needed. This is particularly true for the period beginning in the 1990s when the Montreal Protocol emissions ban stopped the accumulation of CFCs in the atmosphere, causing dissolved CFCs in the ocean to no longer be readily applicable as a simple age tracer and to be subject to a significant back-flux to the atmosphere in some regions [Fine, 2011].

[6] We revisit the paradigm that the dominant control on oceanic ${ }^{14} \mathrm{C}$ is air-sea exchange and demonstrate that shallow- to-deep exchange processes have become the main influence on ${ }^{14} \mathrm{C}$ in recent decades. There are two reasons why the dominant physical control on oceanic ${ }^{14} \mathrm{C}$ has changed. First, the bomb perturbation is now several decades old, longer than the 10 year timescale for ocean-atmosphere equilibration but shorter than the up to several century long timescale associated with ocean circulation and mixing processes [Toggweiler et al., 1989b]. Therefore, most of the bomb-derived ${ }^{14} \mathrm{C}$ has now accumulated in the upper ocean [Naegler and Levin, 2006; Key et al., 2004]. Second, air-sea gradients in $\Delta^{14} \mathrm{C}$ have become substantially smaller. This is mainly due to the rapid decrease in atmospheric $\Delta^{14} \mathrm{C}$ from bomb ${ }^{14} \mathrm{C}$ uptake by the ocean and the terrestrial biosphere, but also to the increase in surface ocean $\Delta^{14} \mathrm{C}$ from bomb ${ }^{14} \mathrm{C}$ accumulation and the dilution of atmospheric $\Delta^{14} \mathrm{C}$ by the burning of ${ }^{14} \mathrm{C}$-free fossil fuels (the "Suess Effect") [Suess, 1955; Levin et al., 2010; Graven et al., 2012a].

[7] To illustrate this change in the rate-limiting step, we use results from the Ocean Carbon-Cycle Model Intercomparison 2 (OCMIP-2) [Orr et al., 1999; Doney et al., 2004], where ${ }^{14} \mathrm{C}$ was simulated by several ocean general circulation models (OGCMs) that utilized the same gas exchange formulation but different transport and mixing schemes. We augment these results with idealized simulations of a onedimensional box diffusion model [Oeschger et al., 1975], where we varied both the vertical diffusivity (mimicking different rates of ocean circulation and mixing) and the global mean gas transfer velocity.

[8] By the 1980s, a large amount of bomb-derived ${ }^{14} \mathrm{C}$ had already infiltrated the ocean, and global inventories of bomb ${ }^{14} \mathrm{C}$ simulated by several ocean models began to stagnate (Figure 1a). Simulations with the box diffusion model show that, while the gas exchange velocity was the strongest determinant of air-sea ${ }^{14} \mathrm{C}$ fluxes in the 1960 s, air-sea ${ }^{14} \mathrm{C}$ fluxes were determined solely by the vertical eddy diffusivity in the $1980 \mathrm{~s}$ (Figure 2). In the $1980 \mathrm{~s},{ }^{14} \mathrm{C}$ fluxes 

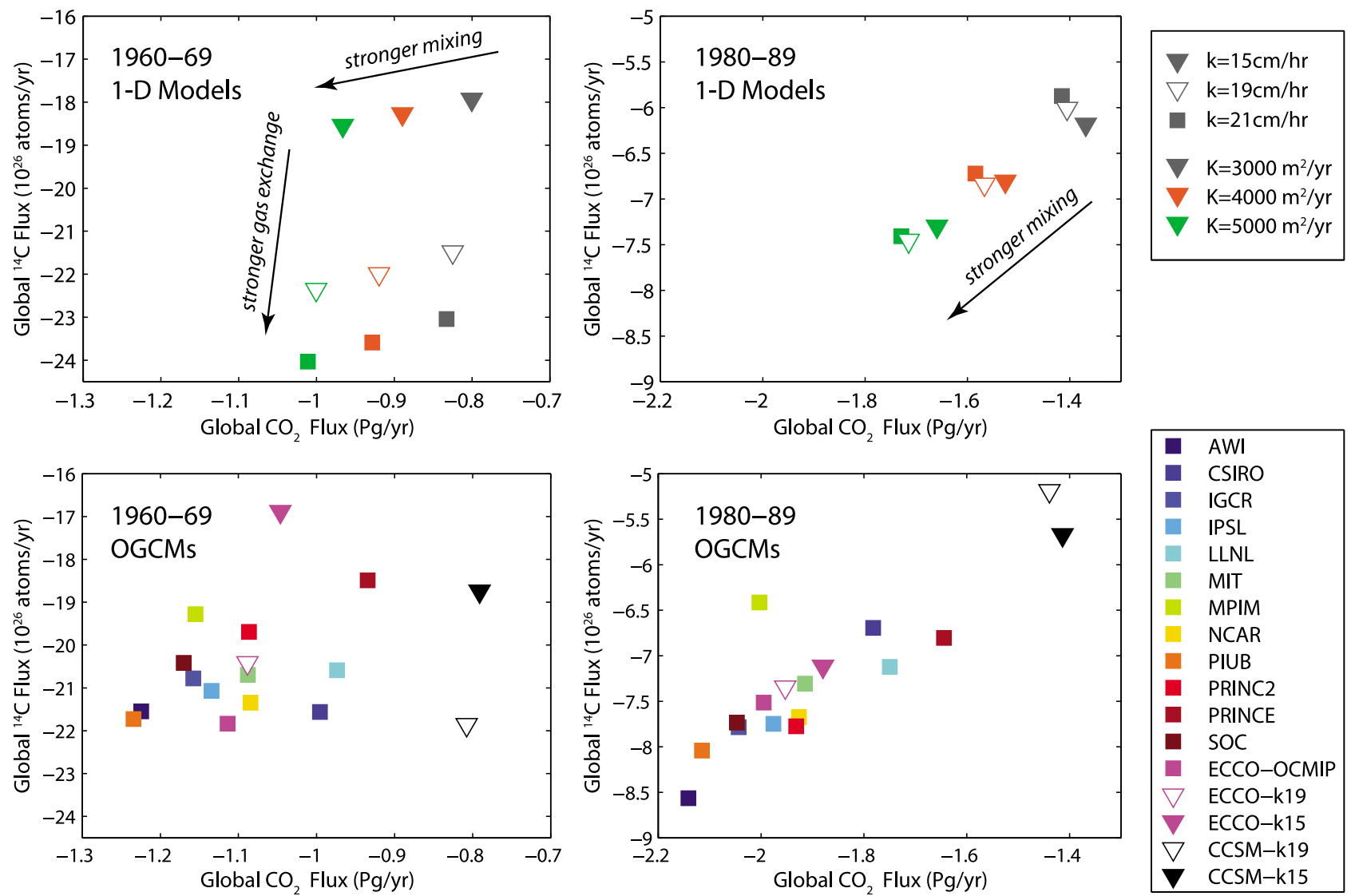

Figure 2. Modeled mean sea-to-air fluxes of ${ }^{14} \mathrm{C}$ versus mean sea-to-air fluxes of $\mathrm{CO}_{2}$ in two time periods: (left) 1960-69 and (right) 1980-89. (top) Fluxes in the 1-D box diffusion model for different parameter sets of gas exchange velocity ( $\mathrm{k}$, shown with symbols) and vertical eddy diffusivity (K, shown with colors). (bottom) Fluxes in the ocean general circulation models from OCMIP-2 and this work. Fluxes are presented from the atmospheric perspective such that the strongest ${ }^{14} \mathrm{C}$ and $\mathrm{CO}_{2}$ sinks are located in the lower left region of each plot.

simulated by the box diffusion model were strongly correlated with anthropogenic $\mathrm{CO}_{2}$ fluxes. Similarly, an improved correlation between fluxes of ${ }^{14} \mathrm{C}$ and anthropogenic $\mathrm{CO}_{2}$ in the 1980 s, in comparison to the 1960 s, can be seen in the OCMIP-2 simulations (Figure 2). These simulations suggest that the dominant control on global oceanic ${ }^{14} \mathrm{C}$ dynamics shifted between the 1960s and 1980s and imply that observations of the changes in oceanic $\Delta^{14} \mathrm{C}$ after 1980 may help to evaluate shallow-to-deep exchange in ocean models that are used to estimate anthropogenic $\mathrm{CO}_{2}$. This is particularly relevant since the accumulation of anthropogenic $\mathrm{CO}_{2}$ in the ocean is not directly observable, but requires elaborate methods to extract this signal from observations [e.g., Gruber et al., 1996; Waugh et al., 2006; Lo Monaco et al., 2005; Khatiwala et al., 2009] with associated uncertainties [Matsumoto and Gruber, 2005; Yool et al., 2010; VázquezRodríguez et al., 2009; Wang et al., 2012]. The availability of ${ }^{14} \mathrm{C}$ data from the repeat hydrographic survey of the Climate Variability and Predictability (CLIVAR) study and the contrast to the data from the WOCE/JGOFS survey conducted in the 1980s and 1990s may help to overcome some of these uncertainties and to permit the establishment of a better constraint for the oceanic uptake of anthropogenic $\mathrm{CO}_{2}$.
[9] A better understanding of the recent dynamics of oceanic ${ }^{14} \mathrm{C}$ is also essential for studies of the global ${ }^{14} \mathrm{C}$ cycle and studies that apply ${ }^{14} \mathrm{C}$ to identify climate-related changes in the global carbon cycle. For example, changes in deep upwelling associated with shifting wind patterns or stratification may result in a measurable $\Delta^{14} \mathrm{C}$ signature in the atmosphere or surface ocean through the anomalous exposure or suppression of aged, ${ }^{14} \mathrm{C}$-depleted water at the surface [Lovenduski et al., 2007; Rodgers et al., 2011; Graven et al., 2012a]. Detection of such climate-related changes to the carbon cycle will require a quantitative understanding of the baseline conditions expected without climate-related effects.

[10] In this paper, we use ocean models and observations to examine the large-scale fluxes, accumulation and redistribution of oceanic ${ }^{14} \mathrm{C}$ in recent decades and to explore the emergent role of shallow-to-deep exchange processes in determining the oceanic ${ }^{14} \mathrm{C}$ dynamics. Using this analysis, we propose new evaluation criteria for ocean models based on the representation of $\Delta^{14} \mathrm{C}$ and its temporal changes, and apply these criteria to model simulations we conducted. We focus on the implications of these results for global-scale ${ }^{14} \mathrm{C}$ and $\mathrm{CO}_{2}$ fluxes, but also discuss how the new observations 
may provide useful model evaluation criteria at regional scales.

\section{Methods}

\subsection{Ocean Modeling}

[11] We conducted hindcast simulations with two global ocean general circulation models: the National Center for Atmospheric Research Community Climate System Model version 3.0 (CCSM) [Smith et al., 2010; Collins et al., 2006; Gent et al., 2006] and an ocean state estimate from the Estimating the Circulation and Climate (ECCO) consortium [Stammer et al., 2004]. The "Abiotic" formulation from the Ocean Carbon-Cycle Model Intercomparison Project 2 (OCMIP-2) was used to simulate dissolved inorganic carbon (DIC) and ${ }^{14} \mathrm{C}$ in DIC [Orr et al., 1999]. The Abiotic formulation neglects sources and sinks of dissolved inorganic carbon caused by the marine biosphere and neglects massdependent fractionation of ${ }^{14} \mathrm{C}$ during air-sea exchange [Toggweiler et al., 1989a].

[12] For CCSM, carbon and ${ }^{14} \mathrm{C}$ were simulated explicitly in the ocean component of the model, the Los Alamos Parallel Ocean Program (POP) model version 2.0.1 [Smith et al., $2010]$, which we ran with a resolution of $0.9-1.9^{\circ}$ latitude by $3.6^{\circ}$ longitude with 25 vertical levels. For the ECCO state estimate, carbon and ${ }^{14} \mathrm{C}$ simulations were performed using the transport matrix method, an efficient "offline" method for simulation of chemical and biological tracers [Khatiwala, 2007]. The ECCO estimate uses a quasi-global configuration of the Massachusetts Institute of Technology's General Circulation Model (MIT GCM) [Marshall et al., 1997], with a resolution of $1^{\circ}$ latitude by $1^{\circ}$ longitude and 23 vertical levels. The ECCO data assimilation strategy, described in detail by Wunsch and Heimbach [2007], involves adjusting air-sea fluxes of heat, momentum and freshwater to bring the model into consistency (within error limits) with various data sources. The result is a dynamically consistent estimate of ocean circulation and hydrography over that period. Here we use a solution (called ECCO-GODAE iteration 2.199) for the period 1992-2004 [Stammer et al., 2004]. Monthly mean transport matrices, representing a climatology over this 13-year assimilation period, were extracted from the model and used to perform the tracer simulations. Further details on the model configurations are provided in Tables S4 and $\mathrm{S} 5$ in Text $\mathrm{S} 1{ }^{1}$

[13] In CCSM, monthly climatological forcing was provided by the Common Ocean-ice Reference Experiments Corrected Normal Year Forcing (CORE-CNYF) [Large and Yeager, 2004] and used to determine both the gas exchange velocity and the model circulation. The CORE-CNYF was used in ECCO to determine the gas exchange velocity only. No year-to-year variations were included in the model forcing.

[14] Local gas exchange velocities were calculated using a quadratic parameterization with wind speed [Wanninkhof, 1992]. We reduced the coefficient in the quadratic parameterization from the original value in order to reflect the recent downward revisions of the global mean gas exchange velocity [Sweeney et al., 2007; Müller et al., 2008; Naegler,

\footnotetext{
${ }^{1}$ Auxiliary materials are available in the HTML. doi:10.1029/ 2012JC008074.
}

2009; Ho et al., 2006]. Coefficients of 0.24 and $0.31 \mathrm{~cm}$ $\mathrm{hr}^{-1} \mathrm{~s}^{2} \mathrm{~m}^{-2}$ were used in two separate simulations of each model. With CORE-CNYF winds this results in global mean gas exchange velocities of $15 \mathrm{~cm} \mathrm{hr}^{-1}$ and $19 \mathrm{~cm} \mathrm{hr}^{-1}$. We refer to the two simulation types as $k 15$ and $k 19$, respectively. An additional simulation of ECCO was conducted using the same coefficient as in OCMIP-2 $\left(0.337 \mathrm{~cm} \mathrm{hr}^{-1} \mathrm{~s}^{2}\right.$ $\mathrm{m}^{-2}$ ) [Wanninkhof, 1992], yielding a global mean gas velocity of $21 \mathrm{~cm} \mathrm{hr}^{-1}$ (this simulation is referred to as ECCO-OCMIP in Figures 1 and 2).

[15] After computing a steady state in each simulation type by running CCSM forward for $5000-8000$ years or by direct calculation using a fast spin-up technique for ECCO [Khatiwala, 2008], we simulated oceanic DIC and ${ }^{14} \mathrm{C}$ in DIC for 1760-2007. For the atmospheric boundary conditions of atmospheric $\mathrm{CO}_{2}$ mole ratio and atmospheric $\Delta^{14} \mathrm{C}$, we used the same records as used in OCMIP-2 for 1760 1989 [Orr et al., 1999] and extended them to 2007 using atmospheric data from 1990 to 2007 [Keeling and Whorf, 2005; Levin et al., 2010; Graven et al., 2012a] (Table S3 in Text S1). Here we will focus on results from 1950 through 2007.

\subsection{Ocean Observations}

[16] We compiled observations of $\Delta^{14} \mathrm{C}$ in DIC from large-scale hydrographic surveys [Broecker and Peng, 1982; Key et al., 2004; Kumamoto et al., 2011a, 2011b; R. Key and A. McNichol, unpublished data, 2012] and individual cruises [Nydal et al., 1998; Graven et al., 2012b; Broecker et al., 1960; Fairhall and Young, 1985; Linick, 1978; Aramaki et al., 2010; Bien et al., 1960, 1965; Druffel et al., 1989; Gamo et al., 1987; Delibrias, 1980; Guilderson et al., 2006; Kumamoto et al., 2002; Leboucher et al., 2004; Masiello et al., 1998; Povinec et al., 2004; Ribbe and Tomczak, 1997; Tsunogai et al., 1995], as well as observations of $\Delta^{14} \mathrm{C}$ in coral records [Brown et al., 1993; Druffel and Griffin, 1995; Druffel, 1996; Druffel et al., 2001; Grumet et al., 2002, 2004; Guilderson and Schrag, 1998a, Guilderson et al., 1998b; Guilderson et al., 2000a, 2004; Morimoto et al., 2004; Mitsuguchi et al., 2004; Schmidt et al., 2004].

[17] We define surface ocean $\Delta^{14} \mathrm{C}$ using observations from all sources collected at depths shallower than $50 \mathrm{~m}$ (Figure 3 and section 3.2). We also use the estimated "natural" $\Delta^{14} \mathrm{C}$ in individual observations from Key et al. [2004] to describe surface ocean $\Delta^{14} \mathrm{C}$ before anthropogenic perturbations. Other than the presentation of "natural" $\Delta{ }^{14} \mathrm{C}$ in the surface ocean in Figure 3, we do not make any separation between "natural" and "bomb" $\Delta^{14} \mathrm{C}$.

[18] We calculate recent changes in $\Delta^{14} \mathrm{C}$ using observations from five hydrographic sections from the World Ocean Circulation Experiment (WOCE) and the South Atlantic Ventilation Experiment (SAVE) in the 1980s-90s [Oceanographic Data Facility, 1992a, 1992b; Key et al., 1996; Key and Quay, 2002], and the repeat Climate Variability and Predictability (CLIVAR) sections completed in the 2000s (available at http://cchdo.ucsd.edu/) [Kumamoto et al., 2011a, 2011b; R. Key and A. McNichol, unpublished data, 2012]. The locations and dates of these sections are given in Table $\mathrm{S} 1$ in Text $\mathrm{S} 1$. We compare $\Delta^{14} \mathrm{C}$ between the two time periods by binning the observations by potential density and latitude or longitude. Comparing changes along potential density rather than depth eliminates most of the 

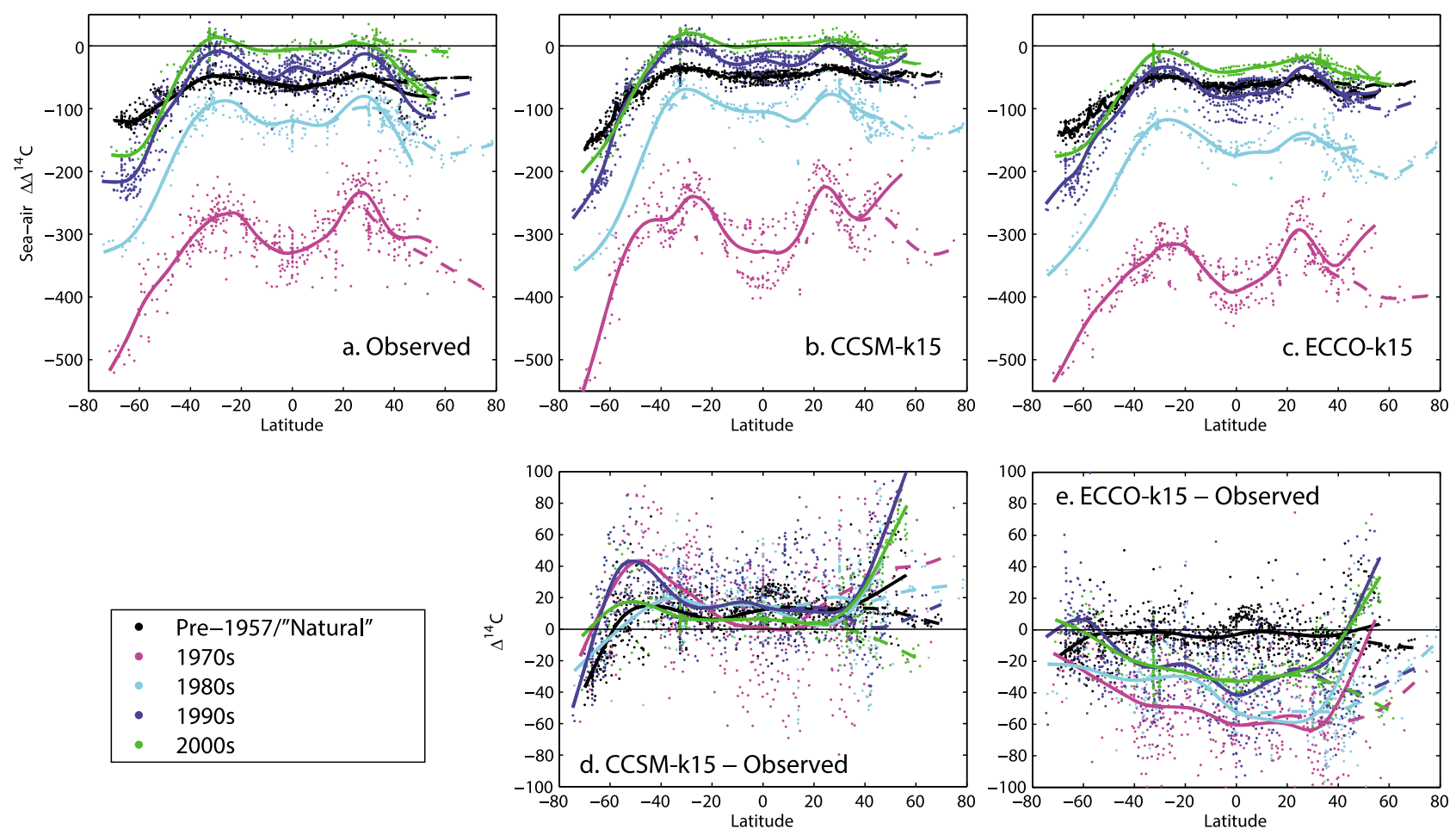

Figure 3. (a) Observations of $\Delta^{14} \mathrm{C}$ at depths of $50 \mathrm{~m}$ or less by decade, with the decadal mean of $\Delta^{14} \mathrm{C}$ in atmospheric $\mathrm{CO}_{2}$ subtracted, versus latitude. Black circles indicate observations from before 1957 or the "Natural" $\Delta^{14} \mathrm{C}$ from GLODAP [Key et al., 2004; Rubin and Key, 2002], with a preindustrial atmospheric $\Delta{ }^{14} \mathrm{C}$ of $0 \%$ subtracted. In subsequent decades, observations of total $\Delta{ }^{14} \mathrm{C}$ are used, i.e., no separation of "natural" and "bomb" components is made. Solid lines show smoothed curves for data in all regions south of $30^{\circ} \mathrm{N}$ and in the North Pacific, north of $30^{\circ} \mathrm{N}$. Dashed lines show smoothed curves for data in all regions south of $30^{\circ} \mathrm{N}$ and in the North Atlantic, north of $30^{\circ} \mathrm{N}$. (b and c) Modeled $\Delta^{14} \mathrm{C}$, interpolated at sampling dates and locations for the observations shown in Figure 3a. (d and e) The difference between modeled and observed $\Delta^{14} \mathrm{C}$. We show the $k 15$ simulations here and in Figures 4 and 5 since they were found to have the best correspondence to the global ${ }^{14} \mathrm{C}$ inventory (section 3.1 and Figure 1).

effect of vertical water mass displacement by intermittent deepening and heaving of potential density layers. This allows the comparison of $\Delta^{14} \mathrm{C}$ in the same water mass between the two time periods, except at locations where significant lateral movements or changes in density have occurred, for example, due to warming or freshwater inputs.

\section{Results}

\subsection{Global Inventories and Fluxes of ${ }^{14} \mathrm{C}$ and $\mathrm{CO}_{2}$}

[19] The global oceanic inventories of anthropogenic $\mathrm{CO}_{2}$ and bomb ${ }^{14} \mathrm{C}$ simulated by CCSM and ECCO are within the range defined by the older-generation models that participated in OCMIP-2 (Figure 1). The anthropogenic $\mathrm{CO}_{2}$ inventory in ECCO is toward the upper end of the model range (115-119 $\mathrm{Pg}$ for 1994). The anthropogenic $\mathrm{CO}_{2}$ inventory in CCSM is at the lower end (81-83 Pg for 1994), and actually outside the uncertainty of Sabine et al.'s [2004] data-based and Khatiwala et al.'s [2009] empirical estimates. Only slight differences in the anthropogenic $\mathrm{CO}_{2}$ inventory result from using different gas exchange velocities in CCSM and ECCO ( $k 15$ versus $k 19$ results in Figure 1, right), confirming the assertion that gas exchange is not the rate limiting step for its oceanic uptake [Broecker and Peng, 1974; Sarmiento et al., 1992].
[20] In contrast, a strong dependence on gas exchange velocity is apparent in the bomb ${ }^{14} \mathrm{C}$ inventory (Figure 1 , left). Simulations using slow gas exchange (CCSM-k15 and $E C C O-k 15)$ have considerably smaller bomb ${ }^{14} \mathrm{C}$ inventories than those with fast gas exchange (CCSM-k19, ECCO-k19 and the OCMIP-2). As demonstrated earlier [e.g., Sweeney et al., 2007], the slow gas exchange simulations show a much better match to observation-based inventory estimates for both the GEOSECS survey of the 1970s and the WOCE survey of the 1990s [Hesshaimer et al., 1994; Peacock, 2004; Key et al., 2004; Sweeney et al., 2007]. By design, the high gas exchange simulations correspond better to Broecker et al.'s [1995] estimate for the GEOSECS survey [Wanninkhof, 1992; Orr et al., 1999], but this has been shown to be biased high [Hesshaimer et al., 1994; Peacock, 2004].

[21] Differences in bomb ${ }^{14} \mathrm{C}$ inventory are also apparent between models that use the same gas exchange formulation (Figure 1, left). The global bomb ${ }^{14} \mathrm{C}$ inventory in CCSM was initially larger than ECCO, but the ECCO inventory surpassed CCSM in $1985(k 19)$ or $1995(k 15)$. This can be attributed to a stabilization of the CCSM inventory in the 1990s while the ECCO inventory continued to grow through 2007. Stabilization of the CCSM inventory is consistent with significantly weaker ${ }^{14} \mathrm{C}$ uptake in the 1980 s, compared to 

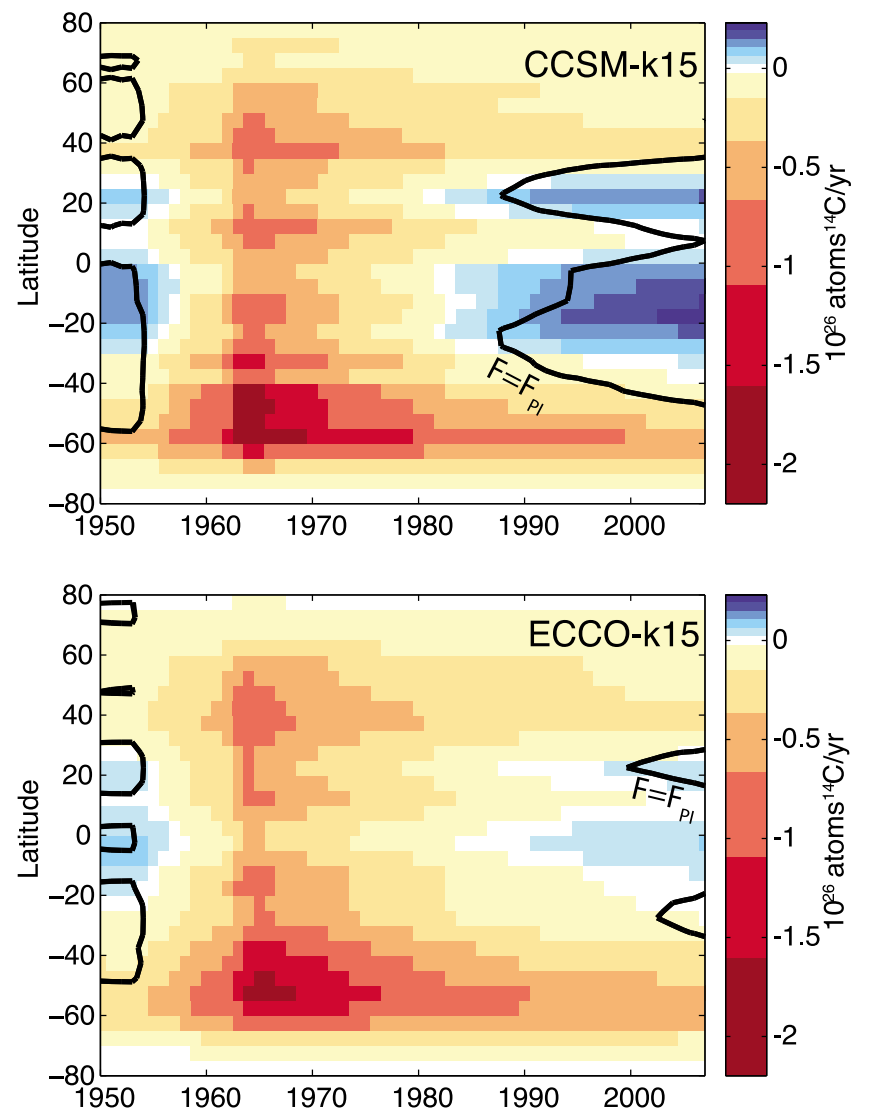

Figure 4. Annual, zonally integrated sea-to-air flux of ${ }^{14} \mathrm{C}$ in $5^{\circ}$ bands in CCSM-k15 and ECCO-k15. Black contours indicate equivalence to the pre-industrial ${ }^{14} \mathrm{C}$ flux in each latitude band.

the other OGCMs (Figure 2). By the 2000s, bomb ${ }^{14} \mathrm{C}$ inventories in CCSM had actually begun decreasing. This signifies that net oceanic uptake of bomb ${ }^{14} \mathrm{C}$ had ceased and bomb ${ }^{14} \mathrm{C}$ was being returned back to the atmosphere. The different behavior of CCSM and ECCO supports the contention that transport and mixing are the dominant processes determining ${ }^{14} \mathrm{C}$ dynamics in recent decades.

\subsection{Evolving Spatial Patterns in ${ }^{14} \mathrm{C}$ Fluxes and Sea-Air $\Delta^{14} \mathrm{C}$ Gradients}

[22] Before anthropogenic perturbations from the Suess Effect and nuclear weapons testing, sea-air $\Delta^{14} \mathrm{C}$ gradients were roughly $-50 \%$ over much of the global ocean, except in the Southern Ocean where sea-air $\Delta^{14} \mathrm{C}$ gradients were more negative than $-100 \%$ (Figure 3a) [Druffel, 2002; Key et al., 2004]. The overall negative sea-air $\Delta^{14} \mathrm{C}$ gradient is a consequence of the global ${ }^{14} \mathrm{C}$ balance that is characterized by cosmogenic production in the upper atmosphere and ocean-interior decay thus requiring a net ${ }^{14} \mathrm{C}$ flux into the ocean at steady state. The largest sea-air $\Delta^{14} \mathrm{C}$ gradients and corresponding flux occurred in the Southern Ocean, where aged Circumpolar Deep Water that is strongly depleted in ${ }^{14} \mathrm{C}$ comes to the surface (Figures 3 and 4) [Broecker and Peng, 1982; Toggweiler et al., 1989a]. In tropical regions, some outgassing of ${ }^{14} \mathrm{C}$ occurred in the preindustrial state as a result of strong $\mathrm{CO}_{2}$ outgassing driven by solubility (Figure 4); however, the net effect of tropical gas exchange was to enhance $\Delta^{14} \mathrm{C}$ in surface waters due to much stronger outgassing of $\mathrm{CO}_{2}$ than ${ }^{14} \mathrm{C}$.

[23] The initiation of intense nuclear weapons testing in 1957 caused a large increase in atmospheric $\Delta^{14} \mathrm{C}$ and seaair $\Delta^{14} \mathrm{C}$ gradients grew by several hundred per mil. Consequently, a strong uptake of ${ }^{14} \mathrm{C}$ occurred throughout the global ocean (Figures 3 and 4) [Broecker and Peng, 1982; Toggweiler et al., 1989b]. The fluxes were largest in the Southern Ocean, between $40^{\circ} \mathrm{S}$ and $65^{\circ} \mathrm{S}$, while local maxima were also present at $15^{\circ} \mathrm{S}, 15^{\circ} \mathrm{N}$ and $40^{\circ} \mathrm{N}$ due to high gas exchange velocities from strong winds (Figure 4). In the 1970s, sea-air $\Delta^{14} \mathrm{C}$ gradients and fluxes began to weaken, but became more spatially variable since spatial variations in the surface ocean concentration of bomb ${ }^{14} \mathrm{C}$ began to matter (Figures 3 and 4) [Broecker and Peng, 1982]. The subtropical gyres had already accumulated substantial bomb ${ }^{14} \mathrm{C}$, while the tropics and high latitudes contained very little bomb ${ }^{14} \mathrm{C}$ in the shallow ocean, despite their high uptake. This is a consequence of more intense dilution with underlying waters that contain low concentrations and horizontal divergence. These processes resulted in spatial variations in the sea-air gradients of $\Delta^{14} \mathrm{C}$ of nearly $100 \%$ within low- to midlatitude regions, i.e., more than 5 times higher than before the bomb tests.

[24] Oceanic uptake of bomb ${ }^{14} \mathrm{C}$ continued in the $1980 \mathrm{~s}$, but slowed through the 1990s and 2000s (Figure 1). Accumulation of ${ }^{14} \mathrm{C}$ in the shallow ocean and the strong decrease in atmospheric $\Delta^{14} \mathrm{C}$ levels resulted in sea-air $\Delta^{14} \mathrm{C}$ gradients in mid- and low latitude regions that were weaker than in the preindustrial state (Figure 3 ). In some areas sea-air $\Delta^{14} \mathrm{C}$ gradients were not only weaker, they had switched from negative to positive, i.e., surface ocean $\Delta^{14} \mathrm{C}$ was even higher than atmospheric $\Delta^{14} \mathrm{C}$. As a result, ${ }^{14} \mathrm{C}$ fluxes reversed sign and began returning bomb ${ }^{14} \mathrm{C}$ to the atmosphere (Figure 4). By 2007 bomb ${ }^{14} \mathrm{C}$ outgassing encompassed $45^{\circ} \mathrm{S}$ to $35^{\circ} \mathrm{N}$ in $\mathrm{CCSM}$, but was restricted to the subtropical gyres in ECCO (Figure 4). At the same time, negative $\Delta^{14} \mathrm{C}$ gradients remained stronger than preindustrial gradients in the North Pacific and Southern Oceans, and bomb ${ }^{14} \mathrm{C}$ uptake continued there through 2007. Clearly, the distribution of ${ }^{14} \mathrm{C}$ fluxes and sea-air $\Delta^{14} \mathrm{C}$ gradients continues to evolve and remains much different than before nuclear weapons testing and fossil fuel combustion.

[25] Comparison to data shows that surface $\Delta^{14} \mathrm{C}$ is generally too high in CCSM and generally much too low in ECCO (Figures 3d and 3e). In CCSM, with the exception of the high latitudes, the positive bias is relatively constant through time, while in ECCO, the bias evolves substantially. ECCO's preindustrial $\Delta^{14} \mathrm{C}$ distribution matches the observations closely but the $\Delta^{14} \mathrm{C}$ distribution in the 1970 s has a very large negative bias that progressively improves until the $1990 \mathrm{~s}$. The negative bias suggests that too much bomb ${ }^{14} \mathrm{C}$ is transported from the surface into deeper water in ECCO. In contrast, the positive surface ocean bias in CCSM indicates that too much ${ }^{14} \mathrm{C}$ accumulated in shallow water and not enough ${ }^{14} \mathrm{C}$ was transported into deeper waters. These model differences have strong effects on the simulated sea-air ${ }^{14} \mathrm{C}$ flux, particularly in recent decades (Figure 4). The most notable effect is an earlier initiation and subsequent expansion of bomb ${ }^{14} \mathrm{C}$ release to the atmosphere from tropical and subtropical ocean regions in CCSM compared to ECCO. 

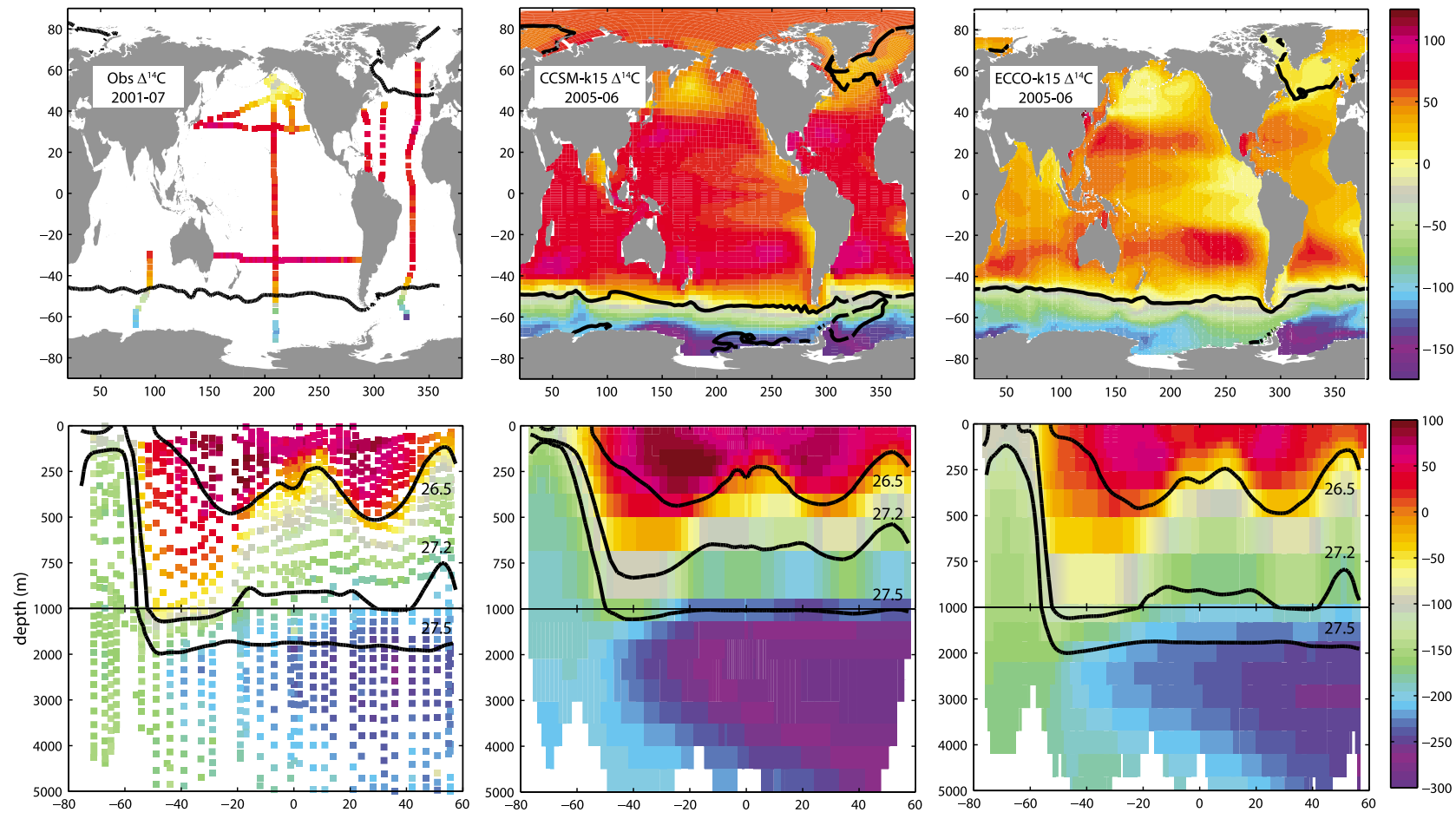

Figure 5. Observed and modeled $\Delta^{14} \mathrm{C}$ (top) at the surface and (bottom) at $150^{\circ} \mathrm{W}$. Surface observations were made between 2001 and 2007, while observations at $150^{\circ} \mathrm{W}$ were made in 2005-06 during the CLIVAR P16 transect. Modeled $\Delta^{14} \mathrm{C}$ shows the average of 2005-06. Black lines indicate the $\sigma_{\theta} 26.5$ surface in the top panels, and the $\sigma_{\theta} 26.5,27.2$ and 27.5 surfaces in the bottom panels. Note the expanded scale at shallow depths in the bottom panels.

The "true" fluxes in the low and temperate latitudes are likely in between the two models.

[26] The strong differences in the simulated present-day distribution of surface ocean $\Delta^{14} \mathrm{C}$ in the two models become even more evident in surface maps (Figure 5). $C C S M-k 15$ exhibits consistently higher $\Delta^{14} \mathrm{C}$ values throughout the low and temperate latitudes than ECCO-k15, while the reverse occurs in the Southern Ocean. The limited surface $\Delta^{14} \mathrm{C}$ observations sampled between 2001 and 2007 show weak $\Delta^{14} \mathrm{C}$ gradients between $40^{\circ} \mathrm{S}$ and $40^{\circ} \mathrm{N}$ (Figures 3 and 5). The observed pattern is in better agreement with CCSM than ECCO. Both models overestimate $\Delta^{14} \mathrm{C}$ in the Northeast Pacific (Figures 3 and 5), though ECCO is nearer to the observations.

\subsection{Changes in Ocean Interior $\Delta{ }^{14} \mathrm{C}$ Over Recent Decades}

[27] The differences in transport between the two models also yield strong differences in the distribution of $\Delta^{14} \mathrm{C}$ in the ocean interior, especially when considering the changes in ${ }^{14} \mathrm{C}$ in the last two decades. Observations along a meridional section of the Central Pacific (P16, 150 $\mathrm{W}$ ) during 2005-06 show that vertical gradients are weak south of $55^{\circ} \mathrm{S}$ (Figure 5) (R. Key and A. McNichol, unpublished data, 2012). North of $55^{\circ} \mathrm{S}, \Delta^{14} \mathrm{C}$ is high at the surface and decreases sharply between 200 and $1500 \mathrm{~m}$ depth. A strong surface $\Delta^{14} \mathrm{C}$ gradient occurs between the Sub-Tropical and Sub-Antarctic Fronts, near to the annual mean outcrop of the 26.5 potential density $\left(\sigma_{\theta}\right)$ surface. Maximum $\Delta^{14} \mathrm{C}$ is found at roughly $250 \mathrm{~m}$ depth and $20^{\circ} \mathrm{N}$ in the Northern Hemisphere, and at a similar but much broader region in the Southern Hemisphere. The simulated vertical $\Delta^{14} \mathrm{C}$ distribution in CCSM has higher $\Delta^{14} \mathrm{C}$ in the upper ocean and lower $\Delta^{14} \mathrm{C}$ in the deep ocean, and consequently stronger vertical $\Delta^{14} \mathrm{C}$ gradients, compared to ECCO.

[28] Changes in $\Delta^{14} \mathrm{C}\left(\Delta \Delta^{14} \mathrm{C}\right)$ between 1991-92 and 2005-06 are clearly discernible along P16, and are larger than $40 \%$ in magnitude in some places (Figure 6) [Key et al., 1996; Jenkins et al., 2010; R. Key and A. McNichol, unpublished data, 2012]. $\Delta \Delta^{14} \mathrm{C}$ is largely negative in shallow water and positive in deeper water, switching sign at roughly $\sigma_{\theta} 26.5$, which lies at $400-500 \mathrm{~m}$ depth in the central subtropical Pacific. In the tropics, $\Delta \Delta^{14} \mathrm{C}$ switched from negative to positive at slightly lower densities $\left(\sigma_{\theta} 26.3\right)$, while in the high latitudes negative $\Delta \Delta^{14} \mathrm{C}$ occurred in denser layers of $\sigma_{\theta} 26.6-27.2$ that are exposed to the surface.

[29] A similar pattern was observed in comparisons between GEOSECS (1970s) and WOCE (1990s) data, although the separation between increasing $\Delta^{14} \mathrm{C}$ and decreasing $\Delta^{14} \mathrm{C}$ occurred at shallower depths [Key, 1997; von Reden et al., 1999].

[30] The observed patterns of $\Delta \Delta^{14} \mathrm{C}$ along P16 between WOCE and CLIVAR are reproduced in simulations of both CCSM and ECCO (Figures 6c and 6d). The magnitude of $\Delta \Delta^{14} \mathrm{C}$ in CCSM is larger than in ECCO, but the two models bracket the observations (Figures 6 and S1). In both models the simulated $\Delta^{14} \mathrm{C}$ increase is insensitive to the gas exchange velocity for dense layers not exposed to the surface 

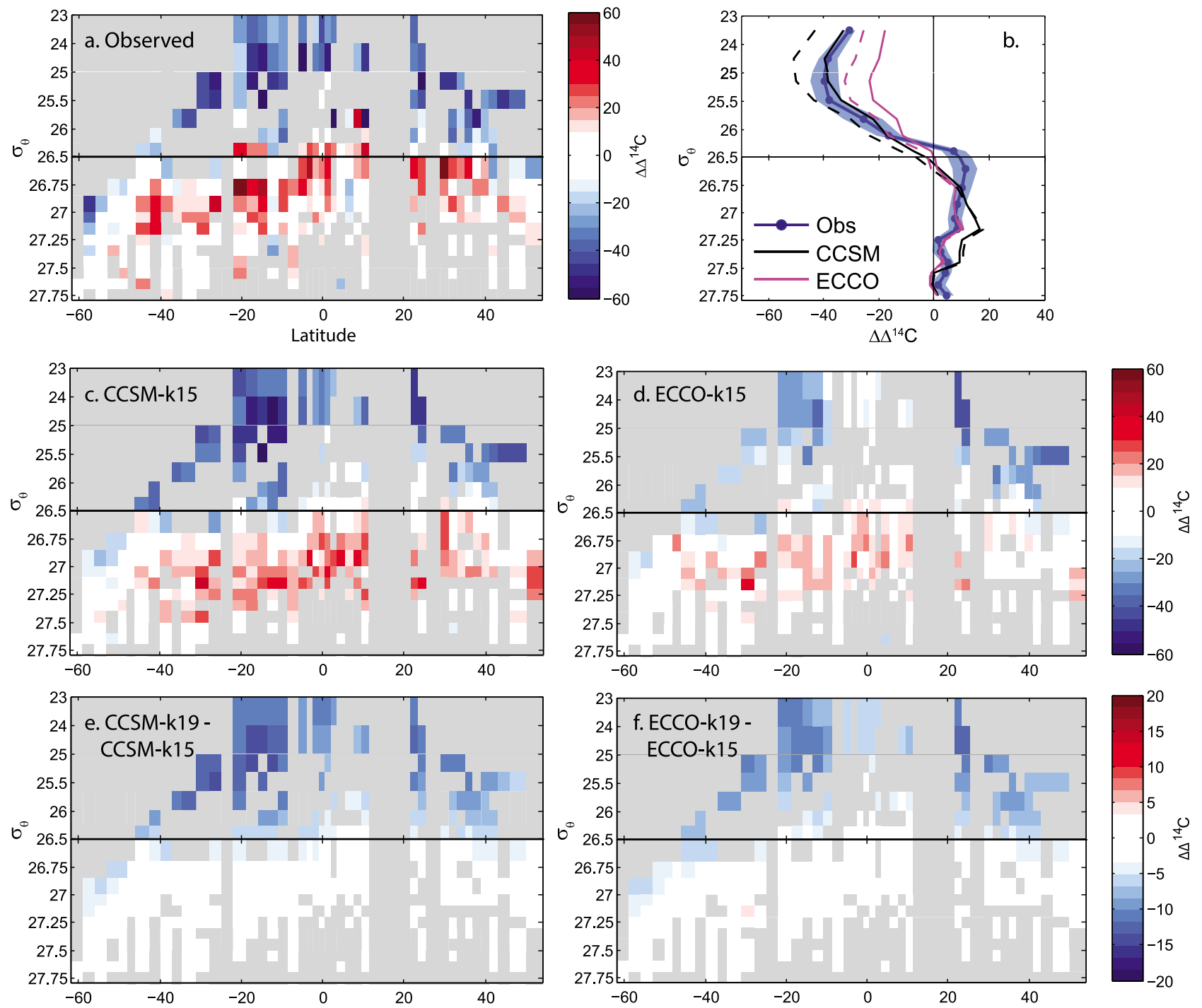

Figure 6. (a) Change in $\Delta^{14} \mathrm{C}\left(\Delta \Delta^{14} \mathrm{C}\right)$ from the WOCE to the CLIVAR surveys for the P16 transect $\left(150^{\circ} \mathrm{W}\right)$, binned by latitude and potential density. (b) Average $\Delta \Delta^{14} \mathrm{C}$ versus potential density in the observations and the models, where solid lines show the simulations with slow gas exchange $(k 15)$ and dashed lines show the simulations with fast gas exchange ( $k 19)$. Blue filled areas show standard error in observed $\Delta \Delta^{14} \mathrm{C}$ across all bins. (c and d) Modeled $\Delta \Delta^{14} \mathrm{C}$ in CCSM and ECCO simulations with slow gas exchange. (e and $\mathrm{f}$ ) The difference in modeled $\Delta \Delta^{14} \mathrm{C}$ for simulations using fast gas exchange rather than slow gas exchange. Modeled $\Delta^{14} \mathrm{C}$ was interpolated at the sample locations and densities and binned in the same manner as the observations.

$\left(\sigma_{\theta} \geq 26.5\right.$; Figures 6e and 6f). For shallower layers $\left(\sigma_{\theta}<\right.$ $26.5)$, the $\Delta^{14} \mathrm{C}$ decrease is somewhat sensitive to the gas exchange velocity. The differences in $\Delta \Delta^{14} \mathrm{C}$ between the two models are larger than the differences in $\Delta \Delta^{14} \mathrm{C}$ within the same model using different gas exchange velocities (Figures $6 \mathrm{~b}$ and $\mathrm{S} 1$ ). Both models simulated the maximum $\Delta \Delta{ }^{14} \mathrm{C}$ to be displaced into denser layers of $\sigma_{\theta} 26.7-27.2$, on average, compared to the observed maximum $\Delta \Delta^{14} \mathrm{C}$ between $\sigma_{\theta} 26.5$ and 26.7 (Figure 6b). The best match to observations is shown by CCSM with slow gas exchange and ECCO with rapid gas exchange (CCSM- $k 15$ and ECCO-k19; Figures $6 \mathrm{~b}$ and $\mathrm{S} 1$ ).

[31] Similar $\Delta \Delta{ }^{14} \mathrm{C}$ patterns are found along a zonal section in the South Pacific (P6; Figure 7) Key et al., 1996;
Kumamoto et al., 2011a] and a meridional section in the South Atlantic (A16S; Figure 7) [Oceanographic Data Facility, 1992a, 1992b; R. Key and A. McNichol, unpublished data, 2012]. $\Delta^{14} \mathrm{C}$ decreased in shallow layers and increased at depth, with the sign change occurring at roughly $\sigma_{\theta} 26.5$ except for areas south of $35^{\circ} \mathrm{S}$ in the Atlantic where decreasing $\Delta^{14} \mathrm{C}$ extended to $\sigma_{\theta}$ 27.0. Again, positive $\Delta \Delta^{14} \mathrm{C}$ in the deeper ocean is insensitive to the gas exchange velocity, and tends to be stronger in CCSM than in ECCO (Figures 7 and $\mathrm{S} 1$ ). In these sections, positive $\Delta \Delta^{14} \mathrm{C}$ showed a better match to ECCO for $\sigma_{\theta}$ greater than 27.0 but a better match to CCSM for $\sigma_{\theta}$ between 26.5 and 27.0, while negative $\Delta \Delta^{14} \mathrm{C}$ was again similar to CCSM with slow gas 

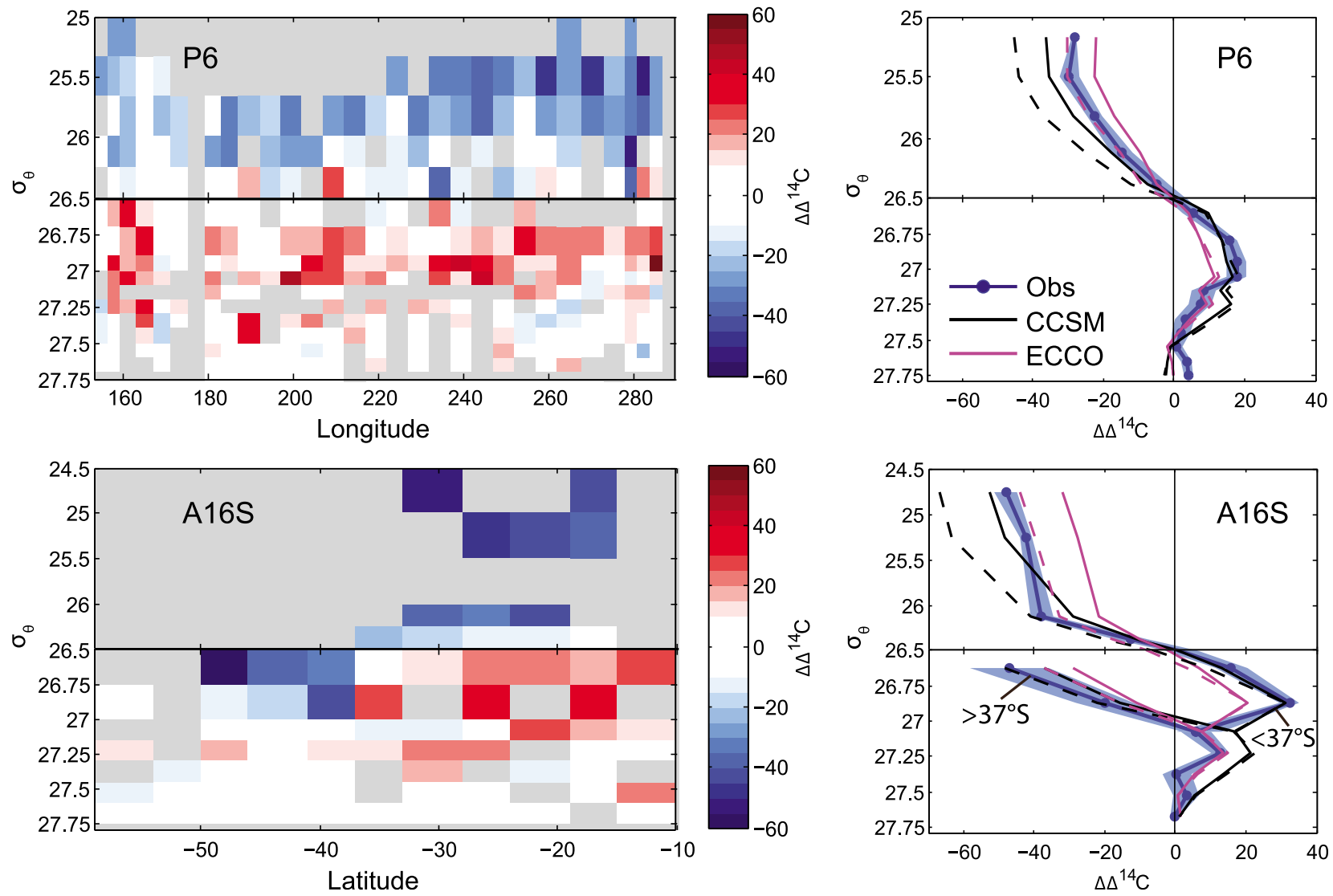

Figure 7. (left) Observed change in $\Delta^{14} \mathrm{C}$ from the WOCE/SAVE to the CLIVAR surveys for the P6 $\left(32^{\circ} \mathrm{S}\right)$ and A16S $\left(30^{\circ} \mathrm{W}\right)$ transects. (right) Average $\Delta \Delta^{14} \mathrm{C}$ versus potential density in the observations and the models, as in Figure 6. For A16S, regions of decreasing $\Delta^{14} \mathrm{C}$ south of $37^{\circ} \mathrm{S}$ are separated from regions of increasing $\Delta^{14} \mathrm{C}$ north of $37^{\circ} \mathrm{S}$ between $\sigma_{\theta} 26.5$ and 27 .

exchange or ECCO with rapid gas exchange (CCSM-k15 or ECCO-k19, Figure 7).

[32] Meridional sections in the Northeast Pacific (P17N; Figure 8) [Key et al., 1996; Kumamoto et al., 2011b] and South Indian (I8S; Figure 8) [Key and Quay, 2002; R. Key and A. McNichol, unpublished data, 2012] similarly show decreases in $\Delta^{14} \mathrm{C}$ for shallow layers of $\sigma_{\theta}<26.5$, extending to higher densities of $\sigma_{\theta} 26.8$ in I8S. The pattern of increasing $\Delta^{14} \mathrm{C}$ in the deeper layers of higher potential density that was observed along P16, P6 and A16S is not present along $\mathrm{P} 17 \mathrm{~N}$ and $\mathrm{I} 8 \mathrm{~S}$.

[33] For I8S, decreasing $\Delta^{14} \mathrm{C}$ that extends to potential densities of 26.8 was reproduced by the models, as was the lack of large-scale increases in $\Delta^{14} \mathrm{C}$ for $\sigma_{\theta} \geq 26.8$. The pattern of $\Delta \Delta^{14} \mathrm{C}$ in I8S reflects the dense waters exposed to the surface in the high southern latitudes and aged water masses at depth, similar to the far southern portions of the P16 and A16S transects (Figures 6 and 7).

[34] For P17N, the absence of an observed increase in $\Delta^{14} \mathrm{C}$ in the deeper layers is not reproduced by the models and may be a consequence of changes in circulation in the North Pacific [Freeland et al., 1997] that are not included in our standard simulations due to our use of constant forcing. Preliminary analysis of CCSM simulations including variable climatic forcing support this interpretation. These simulations indicate that enhanced stratification in this region probably amplified negative $\Delta \Delta^{14} \mathrm{C}$ in shallow layers and reduced positive $\Delta \Delta^{\mathrm{T}} \mathrm{C}$ at depth by restricting the vertical mixing of ${ }^{14} \mathrm{C}$. This interpretation is further supported by the observed trend toward lower oxygen concentrations in the Northeastern Pacific that appears to be caused by reduced ventilation [Deutsch et al., 2006; Whitney et al., 2007].

\section{4. ${ }^{14} \mathrm{C}$ in Shallow and Deep Ocean Reservoirs}

[35] To create a framework to understand recent ${ }^{14} \mathrm{C}$ changes, we aggregate the ocean layers with $\sigma_{\theta}<26.5$, where $\Delta^{14} \mathrm{C}$ decreased, into a "shallow" ocean reservoir and layers with $\sigma_{\theta}$ $\geq 26.5$, where $\Delta^{14} \mathrm{C}$ increased, into a "deep" ocean reservoir. Note that the "deep" reservoir also encompasses high latitude surface regions where dense isopycnals outcrop (Figure 5), including intermediate water formation regions.

[36] For the mid 1990s the observations suggest relatively equal partitioning of bomb ${ }^{14} \mathrm{C}$ into the two reservoirs (Figures 9a and 9b). The models show, however, that the temporal evolutions are very different. The shallow reservoir peaked in the 1980s and is decreasing in its inventory since then, while the deep reservoir is still increasing strongly. The two models agree in these trends, but their absolute partitioning into the two reservoirs is rather different. CCSM has a larger fraction in the shallow reservoir and ECCO has a larger fraction in the deep reservoir (Figures 9a and 9b). The 

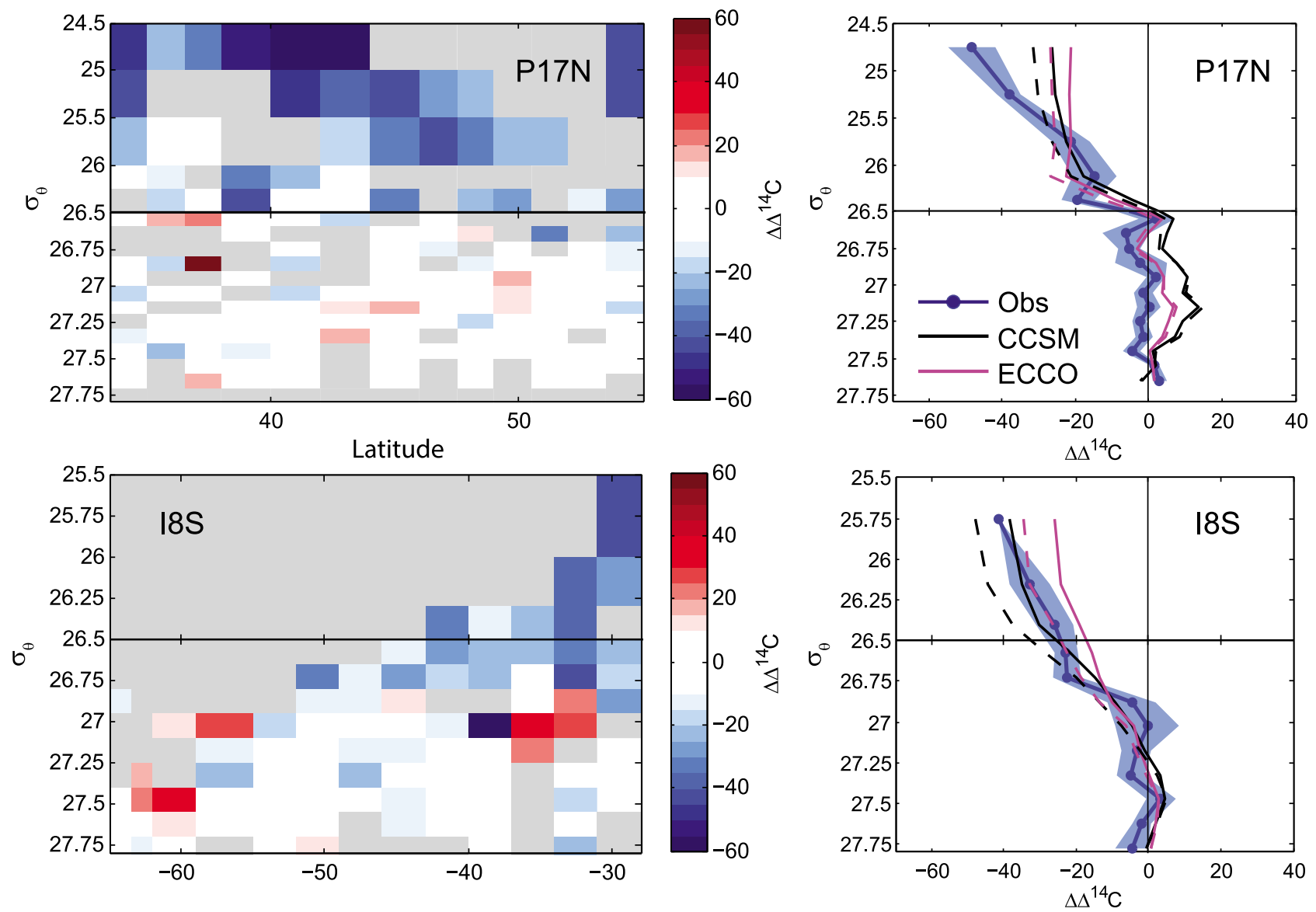

Figure 8. (left) Observed change in $\Delta^{14} \mathrm{C}$ from the WOCE to the CLIVAR surveys for the P17N $\left(135^{\circ} \mathrm{W}\right)$ and I8S $\left(90^{\circ} \mathrm{E}\right)$ transects. (right) Average $\Delta \Delta^{14} \mathrm{C}$ versus potential density in the observations and the models, as in Figure 6.

same pattern is found for anthropogenic $\mathrm{CO}_{2}$ in the deep reservoir, but not in the shallow one (Figures 9c and 9d). Taken together, the ${ }^{14} \mathrm{C}$ and $\mathrm{CO}_{2}$ inventories indicate that transient tracers are introduced more readily into dense waters in ECCO than CCSM.

\subsubsection{Air-Sea Exchange Versus Interior Mixing}

\section{Pathways}

[37] In our two-reservoir framework, there are two pathways for ${ }^{14} \mathrm{C}$ exchange: through the air-sea interface and through the shallow-deep interface. We calculate the ${ }^{14} \mathrm{C}$ exchange flux between the shallow and deep reservoirs by differencing the accumulation rate and the integrated air-sea flux. This exchange flux can occur by diapycnal mixing of ${ }^{14} \mathrm{C}$ across any $\sigma_{\theta} 26.5$ surface or by changes to potential density that cross over $\sigma_{\theta} 26.5$. In particular, seasonal cooling and deepening of the mixed layer that transforms lighter surface water into dense mode and intermediate waters in the Southern Ocean may provide a significant pathway for tracer transport into dense water [Iudicone et al., 2011]. To isolate such near-surface mixing from interior mixing, we repeated the calculations after defining the shallow and deep reservoirs using the annual potential density maximum in local winter, rather than the annual mean (Figures 10c and 10f).

[38] This shallow-deep separation reveals that the early rapid accumulation of bomb ${ }^{14} \mathrm{C}$ is driven by air-sea uptake to the shallow reservoir (Figures 9a, 10a, and 10d). In the 1980s, the transfer of ${ }^{14} \mathrm{C}$ from shallow to deep regions began to outpace atmospheric uptake, resulting in a net loss of ${ }^{14} \mathrm{C}$ from the shallow reservoir. Then, the shallow reservoir began releasing ${ }^{14} \mathrm{C}$ back to the atmosphere in all but one simulation (ECCO-k15), augmenting the loss of ${ }^{14} \mathrm{C}$ by mixing to the deep reservoir. For the deep ocean reservoir the accumulation of bomb ${ }^{14} \mathrm{C}$ (Figure $9 \mathrm{~b}$ ) was initially driven by air-sea ${ }^{14} \mathrm{C}$ uptake, but starting in the 1970 s, the addition of ${ }^{14} \mathrm{C}$ by mixing from the shallow reservoir surpassed air-sea uptake (Figures $10 \mathrm{~b}$ and $10 \mathrm{e}$ ). From the mid1980s to 2007, air-sea uptake accounted for less than half (25-40\%) of the ${ }^{14} \mathrm{C}$ accumulation. In the 1960 s the nearsurface mixing component, that includes the effect of seasonal cooling and mixed layer processes, caused most of the ${ }^{14} \mathrm{C}$ transport from the shallow to the deep reservoir. By the mid-1970s the interior mixing component was the main contributor to shallow-to-deep mixing and to net accumulation of ${ }^{14} \mathrm{C}$ in the deep ocean reservoir (Figure 10). Therefore, simulated recent changes to ${ }^{14} \mathrm{C}$ in the deep inventory mainly reflect interior mixing in the model.

[39] Bomb ${ }^{14} \mathrm{C}$ was introduced to the deep reservoir more readily in ECCO than CCSM as a result of both stronger airsea fluxes and stronger interior mixing (Figures 10h and 10i). Some of the differences can be attributed to density structure. The ECCO density structure is much more consistent with observations than CCSM due to data 

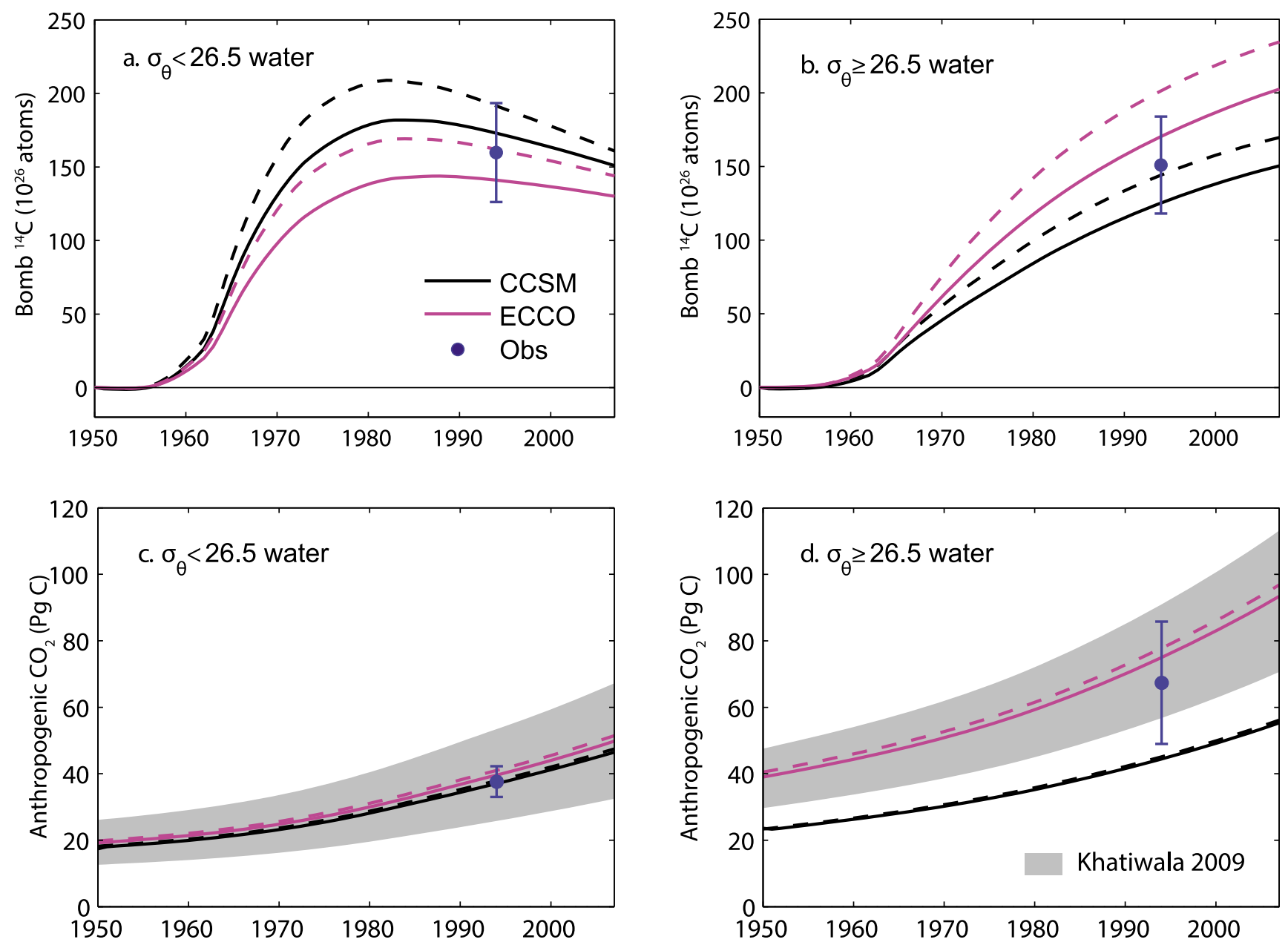

Figure 9. Inventories of (top panel) bomb ${ }^{14} \mathrm{C}$ and (bottom panel) anthropogenic $\mathrm{CO}_{2}$ for the shallow reservoir (left panel) and the deep reservoir (right panel) in CCSM and ECCO. Solid lines show model results with slow gas exchange $(k 15)$ and dashed lines show results with fast gas exchange $(k 19)$. Inventories calculated using the gridded GLODAP data [Key et al., 2004] are shown by blue circles. Anthropogenic $\mathrm{CO}_{2}$ inventories from Khatiwala et al. [2009] are shown as filled areas. Ocean regions not included in GLODAP were omitted from model inventories.

assimilation (section 2.1) [Wunsch and Heimbach, 2007]. In CCSM, a larger fraction of the total ocean surface area is in the shallow reservoir (Table S2 in Text S1) and the $\sigma_{\theta} 26.5$ potential density surface outcrops on average about $4^{\circ}$ too far south (Figure 5). Therefore, some Southern Ocean surface areas with strong winds and consequently high ${ }^{14} \mathrm{C}$ uptake are part of CCSM's shallow reservoir, while they bring ${ }^{14} \mathrm{C}$ into ECCO's deep reservoir.

[40] The large shallow ${ }^{14} \mathrm{C}$ inventory in CCSM has a sustained influence on subsequent ${ }^{14} \mathrm{C}$ fluxes. Since the shallow ocean $\Delta^{14} \mathrm{C}$ is higher, the shallow ocean reaches equilibrium with atmospheric $\Delta^{14} \mathrm{C}$ sooner and thereafter begins to release bomb ${ }^{14} \mathrm{C}$ back to the atmosphere (Figures 4 and $10 \mathrm{~g}$ ). This is reflected in the stabilization of the global bomb ${ }^{14} \mathrm{C}$ inventory in CCSM (Figure 1). This stabilization indicates a balance between shallow ocean release and deep ocean uptake. In contrast, the shallow reservoir of ECCO only begins to release bomb ${ }^{14} \mathrm{C}$ back to the atmosphere after 2000 , if at all.

\subsubsection{Linking Inventory Changes to $\Delta \Delta^{14} \mathrm{C}$}

[41] In the shallow reservoir, the simulated $\Delta \Delta^{14} \mathrm{C}$ and the bomb ${ }^{14} \mathrm{C}$ inventory change are clearly linked. Compared to ECCO, CCSM simulated a stronger loss of bomb ${ }^{14} \mathrm{C}$, resulting in a stronger decrease in $\Delta^{14} \mathrm{C}$ for the WOCE-toCLIVAR period (Figures 6-8 and 10). In the deep reservoir, both models simulated similar bomb ${ }^{14} \mathrm{C}$ accumulation over the WOCE-to-CLIVAR period (Figure 10h), even though CCSM has much stronger $\Delta \Delta^{14} \mathrm{C}$ there (Figures 6-8). This can be explained by the difference in ocean volume into which bomb ${ }^{14} \mathrm{C}$ penetrates. Positive $\Delta \Delta^{14} \mathrm{C}$ extends to roughly $\sigma_{\theta} 27.5$ in both models (Figures 6-8), but the $\sigma_{\theta} 27.5$ horizon is approximately $500 \mathrm{~m}$ shallower in CCSM compared to the observations and to ECCO (Figure 5). Nevertheless, the correspondence with observed $\Delta \Delta^{14} \mathrm{C}$ was no better in ECCO than CCSM. ECCO underestimates the observed $\Delta \Delta^{14} \mathrm{C}$ increase (Figures 6-8 and S1), suggesting that it is too efficient at dispersing ${ }^{14} \mathrm{C}$ within the deep reservoir. 

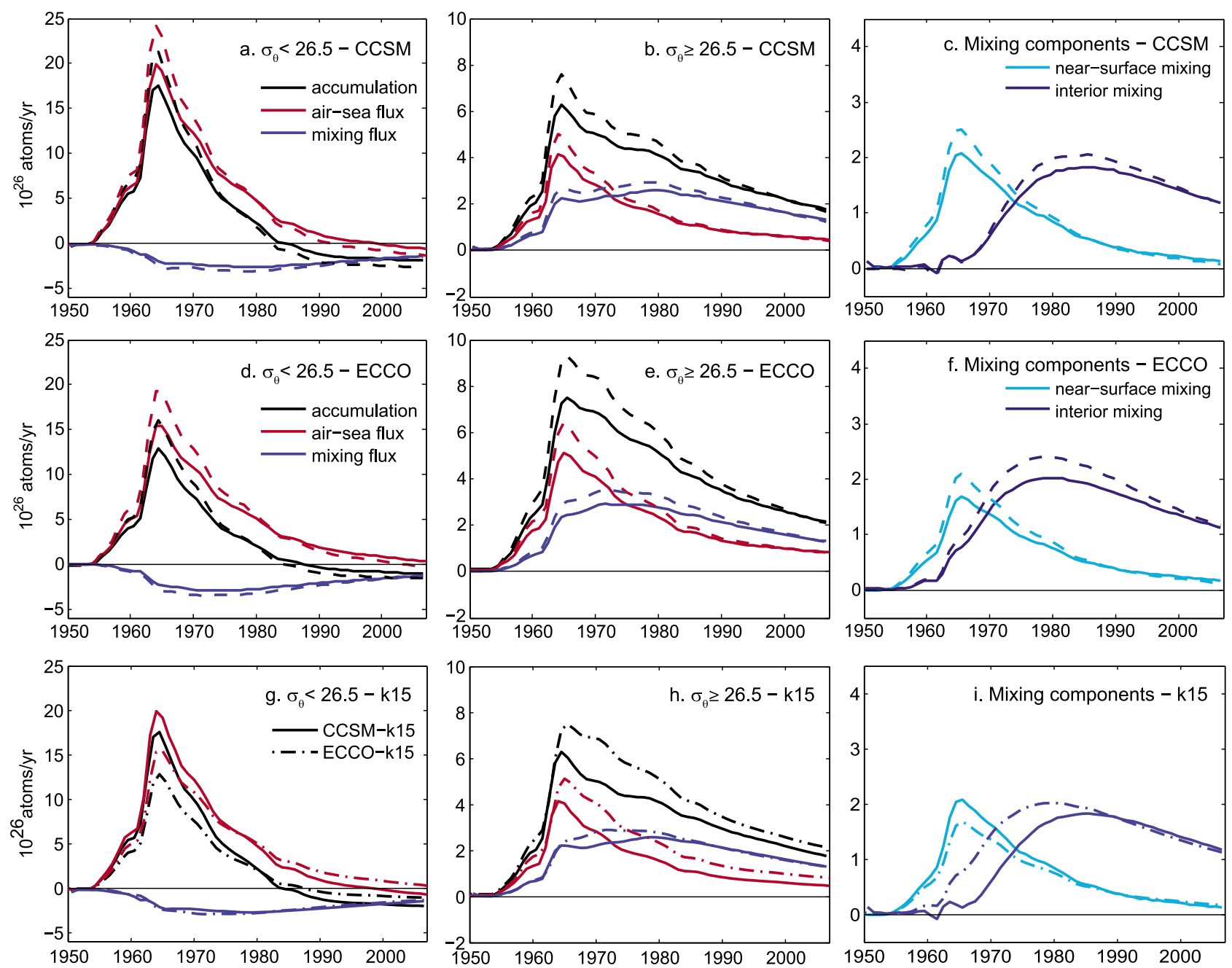

Figure 10. Simulated accumulation and integrated air-sea and mixing fluxes of bomb ${ }^{14} \mathrm{C}$ for (a and d) the shallow reservoir $\left(\sigma_{\theta}<26.5\right)$ and (b and e) the deep reservoir $\left(\sigma_{\theta} \geq 26.5\right)$ in CCSM and ECCO. (c and f) Separation of the mixing flux into near-surface and interior ocean components in CCSM and ECCO. Solid lines show model results with slow gas exchange $(k 15)$ and dashed lines show results with rapid gas exchange ( $k 19)$. (g, h, and i) The CCSM-k15 (solid lines) and ECCO-k15 (dash-dotted) simulations plotted together to enable comparison between the two models.

[42] This effect is not significant for the shallow reservoir because its volume is nearly the same in both models (Figure 5; $300 \mathrm{~m}$, on average).

\subsubsection{Comparison Between Fast and Slow Gas Exchange}

[43] In the shallow reservoir, a higher gas exchange velocity increases the initial bomb ${ }^{14} \mathrm{C}$ inventory, accelerates the switch from sink to source of ${ }^{14} \mathrm{C}$, and subsequently enhances ${ }^{14} \mathrm{C}$ outgassing (Figures 9a, 10a, and 10d). Initially, higher gas exchange velocity also enhances ${ }^{14} \mathrm{C}$ uptake and accumulation in the deep reservoir (Figures 9b, 10b, and 10e). However, from the mid-1990s through 2007 both air-sea uptake and mixing of ${ }^{14} \mathrm{C}$ into the deep reservoir are insensitive to the gas exchange velocity in each model (Figures $10 \mathrm{~b}$ and $10 \mathrm{e}$ ). Consequently, ${ }^{14} \mathrm{C}$ accumulation in the deep reservoir is insensitive to the gas exchange velocity. This is analogous to the relative insensitivity of $\Delta \Delta^{14} \mathrm{C}$ to gas exchange velocity in subsurface water of $\sigma_{\theta} \geq 26.5$ (Figures 6-8 and S1).
[44] This is surprising since air-sea ${ }^{14} \mathrm{C}$ uptake into the dense water of the high latitude ocean is expected to remain sensitive to the gas exchange velocity, particularly in the Southern Ocean where short surface residence times do not allow air-sea equilibration [Ito et al., 2004; Lachkar et al., 2007]. In this way, ${ }^{14} \mathrm{C}$ accumulation in dense waters now seems to resemble the uptake of anthropogenic $\mathrm{CO}_{2}$ into dense waters, which also shows little sensitivity to the magnitude of the gas exchange velocity, even though air-sea gradients of $\mathrm{CO}_{2}$ do not reach equilibration (Figure 9d) [Sarmiento et al., 1992].

[45] Increasing the gas exchange velocity appears to cause compensating effects on bomb ${ }^{14} \mathrm{C}$ uptake in different regions of the Southern Ocean, particularly on either side of the Polar Front (Figure 11). Faster gas exchange causes more ${ }^{14} \mathrm{C}$ uptake south of the Polar Front, but less uptake north of it. South of the Polar Front, surface water in 2005 still contains very little bomb ${ }^{14} \mathrm{C}$ and air-sea gradients remain substantially stronger than preindustrial air-sea gradients 

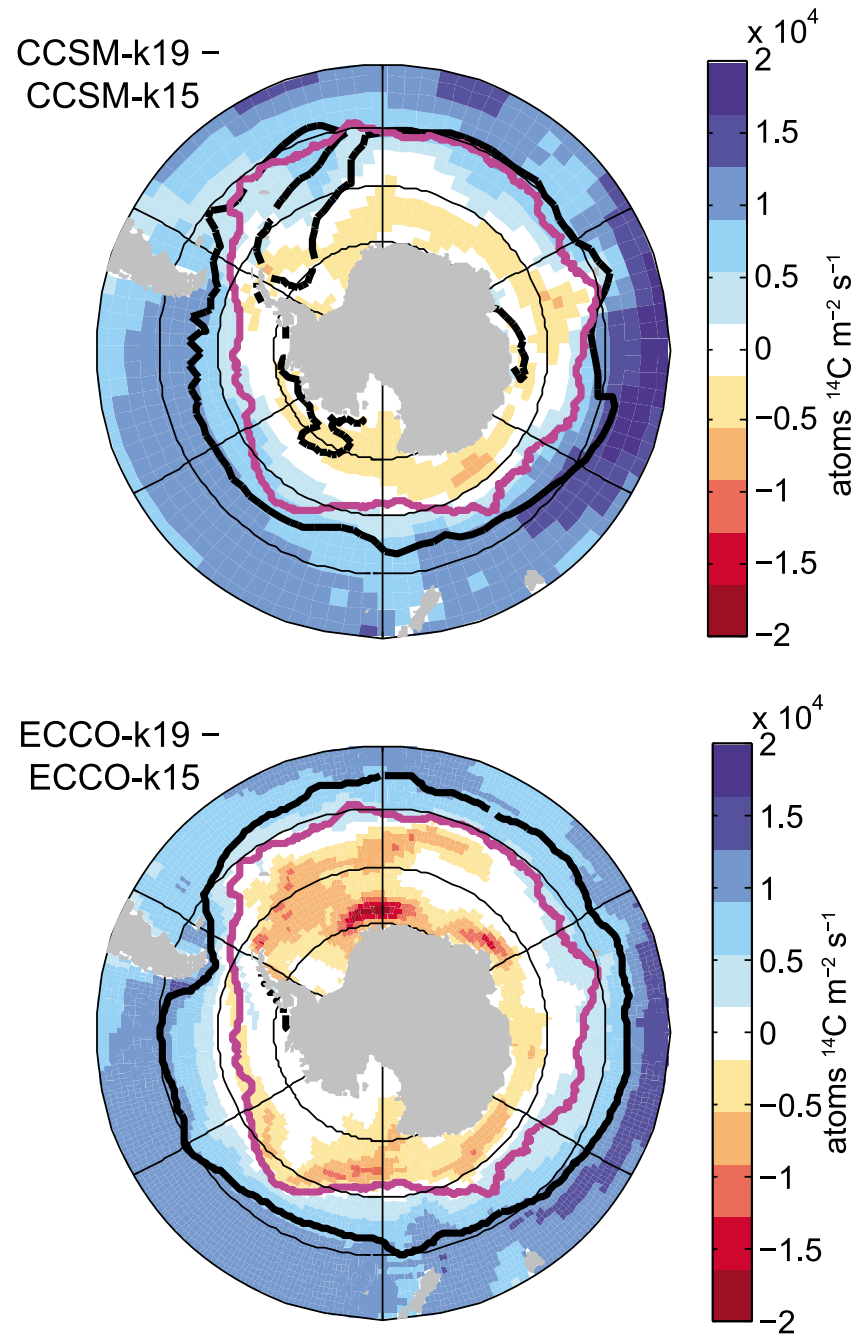

Figure 11. Difference in sea-to-air flux of bomb ${ }^{14} \mathrm{C}$ in 2005 for simulations using rapid gas exchange rather than slow gas exchange. Negative values (red areas) indicate a stronger flux into the ocean. Black contours show the annual mean $\sigma_{\theta} 26.5$ potential density surface in each model. Purple contours show the Antarctic Polar Front, derived from satellite data [Moore et al., 1999].

(Figure 3). Therefore, a higher gas exchange velocity primarily serves to enhance the flux, while it has little impact on the air-sea gradient. In contrast, water north of the Polar Front remains in contact with the atmosphere longer. This allows faster gas exchange to result in more ${ }^{14} \mathrm{C}$ accumulation, higher surface $\Delta^{14} \mathrm{C}$ and hence a reduction of the airsea $\Delta^{14} \mathrm{C}$ gradient. This compensation between enhanced uptake south of the Polar Front and reduced uptake to the north, results in mode and intermediate water having similar bomb ${ }^{14} \mathrm{C}$, regardless of gas exchange velocity.

\section{Discussion and Implication for the Uptake of Anthropogenic $\mathrm{CO}_{2}$}

[46] More than 40 years after the conclusion of intense nuclear weapons testing, patterns of ${ }^{14} \mathrm{C}$ exchange over the global ocean are still much different than during any previous time. Oceanic radiocarbon has not returned to a pre-bomb steady state, nor settled into a new state of equilibrium. Instead, the anthropogenic perturbation of ${ }^{14} \mathrm{C}$ continues to evolve as bomb-derived ${ }^{14} \mathrm{C}$ is redistributed and atmospheric $\Delta^{14} \mathrm{C}$ is continuously diluted by fossil fuel emissions.

[47] The data show that shallow layers $\left(\sigma_{\theta}<26.5\right)$ are presently enriched in bomb ${ }^{14} \mathrm{C}$ relative to both the deep ocean and the atmosphere. The net flux of bomb ${ }^{14} \mathrm{C}$ from the atmosphere into low- and midlatitude ocean regions is now close to zero. In one ocean model simulation a small amount of bomb ${ }^{14} \mathrm{C}$ uptake continues, while these regions are now outgassing bomb ${ }^{14} \mathrm{C}$ in the rest of the simulations.

${ }^{14} \mathrm{C}$ release from the low- and midlatitude ocean can balance or overwhelm the continuing bomb ${ }^{14} \mathrm{C}$ uptake to the high latitude ocean and result in a global ocean ${ }^{14} \mathrm{C}$ inventory that is constant or decreasing over the 1990s and 2000s (Figure 1).

[48] The surface separating layers of increasing and decreasing $\Delta^{14} \mathrm{C}$ in the recent WOCE-to-CLIVAR era is determined exclusively by physical drivers: oceanic transport and mixing processes and the atmospheric $\Delta^{14} \mathrm{C}$ history. This is in contrast to other oceanic biogeochemical horizons that are influenced by biological activity [e.g., Sarmiento et al., 2004; Marinov et al., 2006]. As time progresses since bomb testing, the horizon separating $\Delta^{14} \mathrm{C}$ trends is shifting to denser layers with older ventilation ages (Figures 6-8) [Key, 1997].

[49] The ocean model strengths and deficiencies identified by our $\Delta^{14} \mathrm{C}$ analysis have strong implications for anthropogenic $\mathrm{CO}_{2}$ uptake. Global fluxes of ${ }^{14} \mathrm{C}$ and anthropogenic $\mathrm{CO}_{2}$ simulated by models were shown to be highly correlated after 1980 (Figure 2), with both being dominated by the rate of shallow-to-deep exchange that governs deep ocean accumulation (Figure 9). Therefore, errors identified in the simulated bomb ${ }^{14} \mathrm{C}$ accumulation likely also apply to the simulated anthropogenic $\mathrm{CO}_{2}$ accumulation. Since the model-data comparisons of $\Delta^{14} \mathrm{C}$ indicate that shallow-todeep exchange (from both isopycnal and diapycnal mixing processes), is too efficient in ECCO, one can conclude that it likely accumulates too much anthropogenic $\mathrm{CO}_{2}$ in the deep ocean as well and consequently takes up too much anthropogenic $\mathrm{CO}_{2}$ from the atmosphere. This suggests that $\Delta^{14} \mathrm{C}$ provides unique information on large-scale ocean circulation that is independent from the physical data assimilated by ECCO. Conversely, CCSM probably accumulates too little anthropogenic $\mathrm{CO}_{2}$ in the deep ocean and takes up too little anthropogenic $\mathrm{CO}_{2}$. Our analysis therefore suggests upper and lower limits to the global oceanic $\mathrm{CO}_{2}$ sink of $2.3 \mathrm{Pg} \mathrm{C}$ $\mathrm{yr}^{-1}$ (simulated by ECCO) and $1.7 \mathrm{Pg} \mathrm{C} \mathrm{yr}^{-1}$ (simulated by CCSM) for 1990-2007. A global oceanic $\mathrm{CO}_{2}$ sink in this range is similar to estimates from several other studies [Intergovernmental Panel on Climate Change (IPCC), 2007; Gruber et al., 2009; Khatiwala et al., 2009; Sabine and Tanhua, 2010; Keeling et al., 1996; Manning and Keeling, 2006; Mikaloff Fletcher et al., 2006].

[50] While these upper and lower limits do not improve upon the uncertainty in the oceanic sink for anthropogenic $\mathrm{CO}_{2}$, our work provides an independent check through the evaluation of ocean model transport using ${ }^{14} \mathrm{C}$. Evaluations of a larger group of models and an improved estimate of the rate of change of ${ }^{14} \mathrm{C}$ in the ocean may enable the uncertainty of the $\mathrm{CO}_{2}$ sink to be reduced in addition to enabling 
physical processes in ocean models to be tested and improved further.

[51] Evaluating ocean models with observed $\Delta^{14} \mathrm{C}$ and $\Delta \Delta^{14} \mathrm{C}$ has the advantage that a separation of "natural" and "bomb" components is not required. Previous studies isolated bomb ${ }^{14} \mathrm{C}$ in the ocean using various methods that have significant uncertainties [Broecker et al., 1995; Rubin and Key, 2002; Peacock, 2004] (Figures 1 and 9). For $\Delta \Delta^{14}$ C, anthropogenic influences are large and natural influences associated with water mass variability can be reduced by comparing observations on potential density surfaces as we have done here or, potentially, by more sophisticated techniques. As time passes, ocean circulation and mixing processes will continue to operate over longer timescales and influence $\Delta \Delta^{14} \mathrm{C}$. Therefore, changes in $\Delta^{14} \mathrm{C}$ and other transient tracers such as CFCs are likely to be useful for investigating ocean transport processes in the coming decades, especially when ocean circulation and mixing is expected to change substantially [Fine, 2011].

[52] While we have focused on large-scale patterns, examining finer-scale changes in $\Delta^{14} \mathrm{C}$ revealed by the new CLIVAR measurements (Figures 6-8) could provide insight on ocean ventilation processes occurring in specific regions, similar to previous studies [e.g., Watanabe et al., 1999; Guilderson et al., 2000b; Mahadevan, 2001]. In addition, we have focused on the effect of changing atmospheric $\Delta^{14} \mathrm{C}$ by keeping ocean circulation constant in the models. Examining how oceanic $\Delta^{14} \mathrm{C}$ may be affected by changing ocean circulation could provide insight on climatic variability in the ocean carbon cycle or on anthropogenic carbon-climate feedbacks [Friedlingstein et al., 2006]. For example, identifying climate-related changes in $\Delta^{14} \mathrm{C}$ in the Southern Ocean over the 1990s could help in determining the sensitivity of deep upwelling to strengthening circumpolar winds, a subject currently under debate [Le Quéré et al., 2007; Lovenduski et al., 2007, 2008; Böning et al., 2008].

\section{Summary and Conclusions}

[53] The ocean's response to the input of bomb ${ }^{14} \mathrm{C}$ and atmospheric $\Delta^{14} \mathrm{C}$ dilution from fossil fuel emissions continues to cause significant changes to the air-sea flux of ${ }^{14} \mathrm{C}$ and the oceanic distribution of $\Delta^{14} \mathrm{C}$. We show how the rapid accumulation of bomb ${ }^{14} \mathrm{C}$ in the upper ocean over the last few decades has shifted the control on ${ }^{14} \mathrm{C}$ from air-sea exchange to interior ocean transport and mixing. The evolving distribution of oceanic $\Delta^{14} \mathrm{C}$ is now primarily influenced by the shallow-to-deep exchange processes that also regulate the oceanic sink of anthropogenic $\mathrm{CO}_{2}$.

[54] Model-data comparisons suggest the transfer of bomb ${ }^{14} \mathrm{C}$ and anthropogenic $\mathrm{CO}_{2}$ into the ocean interior is too efficient in the ECCO model because simulated surface $\Delta^{14} \mathrm{C}$ levels are more negative than observed and changes in $\Delta^{14} \mathrm{C}$ between the 1990 s and 2000 s are too weak. In contrast, inefficient transport traps too much bomb ${ }^{14} \mathrm{C}$ near the surface in CCSM, causing higher surface $\Delta^{14} \mathrm{C}$ levels and stronger recent $\Delta^{14} \mathrm{C}$ changes, compared to the observations. These comparisons suggest that CCSM and ECCO represent lower and upper limits to shallow-to-deep exchange of ${ }^{14} \mathrm{C}$ and $\mathrm{CO}_{2}$, lending support to a global ocean sink of anthropogenic $\mathrm{CO}_{2}$ that is stronger than the sink

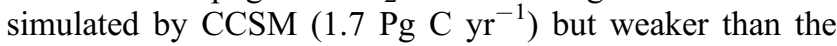

sink simulated by ECCO (2.3 $\left.\mathrm{Pg} \mathrm{C} \mathrm{yr}^{-1}\right)$ for 1990-2007, in agreement with other recent estimates [IPCC, 2007; Gruber et al., 2009; Khatiwala et al., 2009; Sabine and Tanhua, 2010].

[55] Acknowledgments. We are indebted to the numerous sea-going and laboratory scientists that conducted the ocean radiocarbon measurements and made their data available, and to the Carbon Dioxide Analysis Data Center (CDIAC) and the CLIVAR and Carbon Hydrographic Data Office (CCHDO) for hosting the data. This work was financially supported by ETH Zurich. This is LDEO contribution number 7600 .

\section{References}

Aramaki, T., Y. Nojiri, H. Mukai, S. Kushibashi, M. Uchida, and Y. Shibata (2010), Preliminary results of radiocarbon monitoring in the surface waters of the North Pacific, Nucl. Instrum. Phys. Res. B, 268(7-8), 1222-1225, doi:10.1016/j.nimb.2009.10.138.

Bien, G. S., N. W. Rakestraw, and H. E. Suess (1960), Radiocarbon concentration in Pacific Ocean water, Tellus, 12(4), 436-443, doi:10.1111/ j.2153-3490.1960.tb01330.x.

Bien, G. S., N. W. Rakestraw, and H. E. Suess (1965), Radiocarbon in the Pacific and Indian Oceans and its relation to deep water movements, Limnol. Oceanogr., 10, suppl. 5, R25-R37.

Böning, C. W., A. Dispert, M. Visbeck, S. R. Rintoul, and F. U. Schwarzkopf (2008), The response of the Antarctic Circumpolar Current to recent climate change, Nat. Geosci., 1, 864-869, doi:10.1038/ngeo362.

Broecker, W. S., and T. H. Peng (1974), Gas exchange rates between air and sea, Tellus, 26(1-2), 21-35.

Broecker, W. S., and T. H. Peng (1982), Tracers in the Sea, 690 pp., Eldigo, Palisades, N. Y.

Broecker, W. S., R. Gerard, M. Ewing, and B. C. Heezen (1960), Natural radiocarbon in the Atlantic Ocean, J. Geophys. Res., 65(9), 2903-2931, doi:10.1029/JZ065i009p02903.

Broecker, W. S., S. Sutherland, W. Smethie, T. H. Peng, and G. Ostlund (1995), Oceanic radiocarbon: Separation of the natural and bomb components, Global Biogeochem. Cycles, 9, 263-288, doi:10.1029/ 95GB00208.

Brown, T. A., G. W. Farwell, P. M. Grootes, and F. H. Schmidt (1993), Intra-annual variability of the radiocarbon content of corals from the Galapagos Islands, Radiocarbon, 35(2), 245-251.

Collins, W. D., et al. (2006), The Community Climate System Model version 3 (CCSM3), J. Clim., 19, 2122-2143, doi:10.1175/JCLI3761.1.

Delibrias, G. (1980), Carbon-14 in the southern Indian Ocean, Radiocarbon, 22(3), 684-692.

Deutsch, C., S. Emerson, and L. Thompson (2006), Physical-biological interactions in North Pacific oxygen variability, J. Geophys. Res., 111, C09S90, doi:10.1029/2005JC003179.

Doney, S. C., and M. W. Hecht (2002), Antarctic Bottom Water formation and Deep Water chlorofluorocarbon distributions in a global ocean climate model, J. Phys. Oceanogr., 32, 1642-1666, doi:10.1175/15200485(2002)032<1642:ABWFAD $>2.0$.CO;2.

Doney, S. C., et al. (2004), Evaluating global ocean carbon models: The importance of realistic physics, Global Biogeochem. Cycles, 18, GB3017, doi:10.1029/2003GB002150.

Druffel, E. R. M. (1996), Post-bomb radiocarbon records from surface corals of the tropical Atlantic Ocean, Radiocarbon, 38(3), 563-572.

Druffel, E. R. M. (2002), Radiocarbon in corals: Records of the carbon cycle, surface circulation and climate, Oceanography, 15(1), 122-127, doi:10.5670/oceanog.2002.43.

Druffel, E. R. M., and S. Griffin (1995), Regional variability of surface ocean radiocarbon from southern Great Barrier Reef corals, Radiocarbon, 37, 517-524.

Druffel, E. R. M., P. M. Williams, K. L. Robertson, S. Griffin, A. J. T. Jull, and D. Donahue (1989), Radiocarbon in dissolved organic and inorganic carbon from the central North Pacific, Radiocarbon, 31, 523-532.

Druffel, E. R. M., S. Griffin, T. Guilderson, M. Kashgarian, and D. Schrag (2001), Changes of subtropical North Pacific radiocarbon and correlation with climate variability, Radiocarbon, 43(1), 15-25.

Dutay, J.-C., et al. (2002), Evaluation of ocean model ventilation with CFC11: Comparison of 13 global ocean models, Ocean Modell., 4(2), 89-120, doi:10.1016/S1463-5003(01)00013-0.

Fairhall, A. W., and J. A. Young (1985), Historical ${ }^{14} \mathrm{C}$ measurements from the Atlantic, Pacific, and Indian Oceans, Radiocarbon, 27(3), 473-507.

Fine, R. A. (2011), Observations of CFCs and $\mathrm{SF}_{6}$ as ocean tracers, Annu. Rev. Mar. Sci., 3, 173-195, doi:10.1146/annurev.marine.010908.163933.

Freeland, H., K. Denman, C. S. Wong, F. Whitney, and R. Jacques (1997), Evidence of change in the winter mixed layer in the northeast Pacific 
Ocean, Deep Sea Res., Part I, 44, 2117-2129, doi:10.1016/S0967-0637 (97)00083-6.

Friedlingstein, P., et al. (2006), Climate-carbon cycle feedback analysis: Results from the C4MIP model intercomparison, J. Clim., 19, 3337 3353, doi:10.1175/JCLI3800.1

Gamo, T., Y. Horibe, and H. Kobayashi (1987), Comparison of oceanic $\Delta^{14} \mathrm{C}$ data with those of GEOSECS: Vertical profiles in 1973(GEOSECS) and in 1980 at $\left(30^{\circ} \mathrm{N}, 170^{\circ} \mathrm{E}\right)$ in the northwestern Pacific Ocean, Radiocarbon, 29(1), 53-56.

Gent, P. R., F. O. Bryan, G. Danabasoglu, K. Lindsay, D. Tsumune, M. W. Hecht, and S. C. Doney (2006), Ocean chlorofluorocarbon and heat uptake during the twentieth century in the CCSM3, J. Clim., 19, 2366-2381, doi:10.1175/JCLI3758.1.

Graven, H. D., T. P. Guilderson, and R. F. Keeling (2012a), Observations of radiocarbon in $\mathrm{CO}_{2}$ at La Jolla, California, USA 1992-2007, J. Geophys. Res., 117, D02302, doi:10.1029/2011JD016533.

Graven, H. D., A. Kozyr, and R. M. Key (2012b), Historical observations of oceanic radiocarbon conducted prior to GEOSECS, http://cdiac.ornl.gov/ ftp/oceans/Historical_C14_obs/, Carbon Dioxide Inf. Anal. Cent. (CDIAC), Oak Ridge Natl. Lāab., Oak Ridge, Tenn.

Gruber, N., J. L. Sarmiento, and T. F. Stocker (1996), An improved method for detecting anthropogenic $\mathrm{CO}_{2}$ in the oceans, Global Biogeochem. Cycles, 10(4), 809-837, doi:10.1029/96GB01608.

Gruber, N., et al. (2009), Oceanic sources, sinks, and transport of atmospheric $\mathrm{CO}_{2}$, Global Biogeochem. Cycles, 23, GB1005, doi:10.1029/ 2008 GB003349.

Grumet, N. S., T. P. Guilderson, and R. B. Dunbar (2002), Meridional transport in the Indian Ocean traced by coral radiocarbon, J. Mar. Res., 60(5), 725-742, doi:10.1357/002224002762688713.

Grumet, N. S., et al. (2004), Coral radiocarbon records of Indian Ocean water mass mixing and wind-induced upwelling along the coast of Sumatra Indonesia, J. Geophys. Res., 109, C05003, doi:10.1029/2003JC002087.

Guilderson, T. P., and D. P. Schrag (1998a), Abrupt shift in subsurface temperatures in the tropical Pacific associated with changes in El Niño, Science, 281(5374), 240-243, doi:10.1126/science.281.5374.240.

Guilderson, T. P., D. P. Schrag, M. Kasharian, and J. Southon (1998b), Radiocarbon variability in the western equatorial Pacific inferred from a high-resolution coral record from Nauru Island, J. Geophys. Res., 103(C11), 24,641-24,650, doi:10.1029/98JC02271.

Guilderson, T. P., D. P. Schrag, E. Goddard, M. Kashgarian, G. M. Wellington, and B. K. Linsley (2000a), Southwest subtropical Pacific surface water radiocarbon in a high-resolution coral record, Radiocarbon, 42(2), 249-256.

Guilderson, T. P., K. Caldeira, and P. B. Duffy (2000b), Radiocarbon as a diagnostic tracer in ocean and carbon cycle modeling, Global Biogeochem. Cycles, 14(3), 887-902, doi:10.1029/1999GB001192.

Guilderson, T. P., D. P. Schrag, and M. A. Cane (2004), Surface water mixing in the Solomon Sea as documented by a high-resolution coral ${ }^{14} \mathrm{C}$ record, J. Clim., 17, 1147-1156, doi:10.1175/1520-0442(2004)017<1147: SWMITS $>2.0 . \mathrm{CO} ; 2$

Guilderson, T. P., E. B. Roark, P. D. Quay, S. R. Flood Page, and C. Moy (2006), Seawater radiocarbon evolution in the Gulf of Alaska: 2002 observations, Radiocarbon, 48, 1-15.

Hesshaimer, V., M. Heimann, and I. Levin (1994), Radiocarbon evidence for a smaller oceanic carbon dioxide sink than previously believed, Nature, 370, 201-203, doi:10.1038/370201a0.

Ho, D. T., C. S. Law, M. J. Smith, P. Schlosser, M. Harvey, and P. Hill (2006), Measurements of air-sea gas exchange at high wind speeds in the Southern Ocean: Implications for global parameterizations, Geophys. Res. Lett., 33, L16611, doi:10.1029/2006GL026817.

Intergovernmental Panel on Climate Change (IPCC) (2007), Climate Change 2007: The Physical Science Basis. Contribution of Working Group I to the Fourth Assessment Report of the Intergovernmental Panel on Climate Change, edited by S. Solomon et al., Cambridge Univ. Press, Cambridge, U. K

Ito, T., J. Marshall, and M. Follows (2004), What controls the uptake of transient tracers in the Southern Ocean?, Global Biogeochem. Cycles, 18, GB2021, doi:10.1029/2003GB002103.

Iudicone, D., et al. (2011), Water masses as a unifying framework for understanding the Southern Ocean carbon cycle, Biogeosciences, 8, 1031-1052, doi:10.5194/bg-8-1031-2011.

Jenkins, W. J., K. L. Elder, A. P. McNichol, and K. von Reden (2010), The passage of the bomb radiocarbon pulse into the Pacific Ocean, Radiocarbon, 52(2-3), 1182-1190.

Keeling, C. D., and T. P. Whorf (2005), Atmospheric $\mathrm{CO}_{2}$ records from sites in the SIO air sampling network, in Trends: A Compendium of Data on Global Change, Carbon Dioxide Inf. Anal. Cent., Oak Ridge Natl. Lab., Oak Ridge, Tenn., doi:10.3334/CDIAC/atg.012.
Keeling, R. F., S. C. Piper, and M. Heimann (1996), Global and hemispheric $\mathrm{CO}_{2}$ sinks deduced from changes in atmospheric $\mathrm{O}_{2}$ concentration, Nature, 381, 218-221, doi:10.1038/381218a0

Key, R. M. (1997), Changes in the Pacific Ocean distribution of radiocarbon, WOCE Implementation Rep. 9, U.S. World Ocean Circ. Exp. Off., College Station, Tex

Key, R. M., and P. D. Quay (2002), U.S. WOCE Indian Ocean Survey: Final report for radiocarbon, Tech. Rep. 02-1, Ocean Tracer Lab., Atmos. and Oceanic Sci. Program, Princeton Univ., Princeton, N. J.

Key, R. M., P. D. Quay, G. A. Jones, A. P. McNichol, K. F. von Reden, and R. J. Schneider (1996), WOCE AMS radiocarbon I: Pacific Ocean results (P6, P16 and P17), Radiocarbon, 38(3), 425-518.

Key, R. M., A. Kozyr, C. L. Sabine, K. Lee, R. Wanninkhof, J. L. Bullister, R. A. Feely, F. J. Millero, C. Mordy, and T.-H. Peng (2004), A global ocean carbon climatology: Results from Global Data Analysis Project (GLODAP), Global Biogeochem. Cycles, 18, GB4031, doi:10.1029/ $2004 \mathrm{~GB} 002247$

Khatiwala, S. (2007), A computational framework for simulation of biogeochemical tracers in the ocean, Global Biogeochem. Cycles, 21, GB3001, doi:10.1029/2007GB002923.

Khatiwala, S. (2008), Fast spin up of ocean biogeochemical models using matrix-free Newton-Krylov, Ocean Modell., 23, 121-129, doi:10.1016/ j.ocemod.2008.05.002.

Khatiwala, S., F. Primeau, and T. Hall (2009), Reconstruction of the history of anthropogenic $\mathrm{CO}_{2}$ concentrations in the ocean, Nature, 462, 346-349, doi:10.1038/nature08526.

Krakauer, N. Y., J. T. Randerson, F. W. Primeau, N. Gruber, and D. Menemenlis (2006), Carbon isotope evidence for the latitudinal distribution and wind speed dependence of the air-sea gas transfer velocity, Tellus, Ser. B, 58(5), 390-417, doi:10.1111/j.1600-0889.2006.00223.x.

Kumamoto, Y., A. Murata, C. Saito, M. Honda, and M. Kusakabe (2002), Bomb radiocarbon invasion into the northwest North Pacific, Deep Sea Res., Part II, 49, 5339-5351, doi:10.1016/S0967-0645(02)00194-7.

Kumamoto, Y., A. Murata, S. Watanabe, and M. Fukasawa (2011a), Temporal and spatial variations in bomb-produced radiocarbon along BEAGLE2003 lines-Revisits of WHP P06, A10, and I03/04 in the Southern Hemisphere oceans, Prog. Oceanogr., 89, 49-60, doi:10.1016/j.pocean.2010.12.007.

Kumamoto, Y. A. Murata, S. Watanabe, and M. Fukasawa (2011b) Decadal changes in the bomb-produced radiocarbon in the Pacific Ocean from the 1990s to 2000s, in Proceedings, 2011 8th International Conference on Fuzzy Systems and Knowledge Discovery, edited by Y. Ding et al., pp. 2497-2499, Inst. of Electr. and Electron. Eng., Piscataway, N. J.

Lachkar, Z., J. C. Orr, J. C. Dutay, and P. Delecluse (2007), Effect of mesoscale eddies on global ocean distributions of CFC-11, C-14, and $\mathrm{CO}_{2}$, Ocean Sci., 3, 461-482, doi:10.5194/os-3-461-2007.

Large, W., and S. Yeager (2004), Diurnal to decadal global forcing for ocean and sea-ice models: The datasets and flux climatologies, Tech. Note NCAR/TN-460+STR, Natl. Cent. for Atmos. Res., Boulder, Colo.

Le Quéré, C., et al. (2007), Saturation of the Southern Ocean $\mathrm{CO}_{2}$ sink due to recent climate change, Science, 316, 1735-1738, doi:10.1126/ science. 1136188 .

Leboucher, V., P. Jean-Baptiste, E. Fourré, M. Arnold, and M. Fieux (2004), Oceanic radiocarbon and tritium on a transect between Australia and Bali (eastern Indian Ocean), Radiocarbon, 46(2), 567-581.

Levin, I., et al. (2010), Observations and modelling of the global distribution and long-term trend of atmospheric ${ }^{14} \mathrm{CO}_{2}$, Tellus, Ser. B, 62(1), $26-46$.

Linick, T. W. (1978), La Jolla measurements of radiocarbon in the oceans, Radiocarbon, 20, 333-359.

Lo Monaco, C., N. Metzl, A. Poisson, C. Brunet, and B. Schauer (2005), Anthropogenic $\mathrm{CO}_{2}$ in the Southern Ocean: Distribution and inventory at the Indian-Atlantic boundary (World Ocean Circulation Experiment line I6), J. Geophys. Res., 110, C06010, doi:10.1029/2004JC002643.

Lovenduski, N. S., N. Gruber, S. C. Doney, and I. D. Lima (2007) Enhanced $\mathrm{CO}_{2}$ outgassing in the Southern Ocean from a positive phase of the Southern Annular Mode, Global Biogeochem. Cycles, 21, GB2026, doi:10.1029/2006GB002900.

Lovenduski, N. S., N. Gruber, and S. C. Doney (2008), Toward a mechanistic understanding of the decadal trends in the Southern Ocean carbon sink, Global Biogeochem. Cycles, 22, GB3016, doi:10.1029/2007GB003139.

Mahadevan, A. (2001), An analysis of bomb radiocarbon trends in the Pacific, Mar. Chem., 73, 273-290, doi:10.1016/S0304-4203(00)00113-4. Manning, A. C., and R. F. Keeling (2006), Global oceanic and land biotic carbon sinks from the Scripps atmospheric oxygen flask sampling network, Tellus, Ser. B, 58, 95-116, doi:10.1111/j.1600-0889.2006.00175.x

Marinov, I., A. Gnanadesikan, J. R. Toggweiler, and J. L. Sarmiento (2006) The Southern Ocean biogeochemical divide, Nature, 441, 964-967, doi: $10.1038 /$ nature 04883 
Marshall, J., A. Adcroft, C. Hill, L. Perelman, and C. Heisey (1997), A finite-volume, incompressible Navier Stokes model for studies of the ocean on parallel computers, J. Geophys. Res., 102, 5753-5766, doi:10.1029/96JC02775.

Masiello, C. A., E. R. M. Druffel, and J. E. Bauer (1998), Distributions of dissolved organic and inorganic carbon and radiocarbon in the eastern North Pacific continental margin, Deep Sea Res., Part II, 45, 689-713, doi:10.1016/S0967-0645(97)00098-2.

Matsumoto, K., and N. Gruber (2005), How accurate is the estimation of anthropogenic carbon in the ocean? An evaluation of the $\Delta \mathrm{C}^{*}$ method, Global Biogeochem. Cycles, 19, GB3014, doi:10.1029/2004GB002397.

Matsumoto, K., et al. (2004), Evaluation of ocean carbon cycle models with data-based metrics, Geophys. Res. Lett., 31, L07303, doi:10.1029/ 2003GL018970

Mikaloff Fletcher, S. E., et al. (2006), Inverse estimates of anthropogenic $\mathrm{CO}_{2}$ uptake, transport, and storage by the ocean, Global Biogeochem. Cycles, 20, GB2002, doi:10.1029/2005GB002530.

Mitsuguchi, T., et al. (2004), High-resolution ${ }^{14} \mathrm{C}$ analyses of annually banded coral skeletons from Ishigaki Island, Japan: Implications for oceanography, Nucl. Instrum. Phys. Res. B, 223-224, 455-459, doi:10.1016/j.nimb.2004.04.086.

Moore, J. K., M. R. Abbott, and J. G. Richman (1999), Location and dynamics of the Antarctic Polar Front from satellite sea surface temperature data, J. Geophys. Res., 104(C2), 3059-3073.

Morimoto, M., K. Hiroyuki, S. Yasuyuki, and K. Hajime (2004), Seasonal radiocarbon variation of surface seawater recorded in a coral from Kika Island, subtropical northwestern Pacific, Radiocarbon, 46(2), 643-648.

Müller, S. A., F. Joos, G.-K. Plattner, N. R. Edwards, and T. F. Stocker (2008), Modeled natural and excess radiocarbon: Sensitivities to the gas exchange formulation and ocean transport strength, Global Biogeochem. Cycles, 22, GB3011, doi:10.1029/2007GB003065.

Naegler, T. (2009), Reconciliation of excess ${ }^{14} \mathrm{C}$-constrained global $\mathrm{CO}_{2}$ piston velocity estimates, Tellus, Ser. B, 61(2), 372, doi:10.1111/j.16000889.2008.00408.x.

Naegler, T., and I. Levin (2006), Closing the global radiocarbon budget 1945-2005, J. Geophys. Res., 111, D12311, doi:10.1029/2005JD006758.

Naegler, T., P. Ciais, K. Rodgers, and I. Levin (2006), Excess radiocarbon constraints on air-sea gas exchange and the uptake of $\mathrm{CO}_{2}$ by the oceans, Geophys. Res. Lett., 33, L11802, doi:10.1029/2005GL025408.

Neftel, A., E. Moor, H. Oeschger, and B. Stauffer (1985), Evidence from polar ice cores for the increase in atmospheric $\mathrm{CO}_{2}$ in the past two centuries, Nature, 315, 45-47, doi:10.1038/315045a0.

Nydal, R. (1963), Increase in radiocarbon from the most recent series of thermonuclear tests, Nature, 200(4903), 212-214, doi:10.1038/ $200212 \mathrm{a} 0$.

Nydal, R., A. L. Brenkert, and T. A. Boden (1998), Carbon-14 measurements in surface water $\mathrm{CO}_{2}$ from the Atlantic, Indian and Pacific Oceans, 1965-1994, Rep. NDP-057A, Carbon Dioxide Inf. Anal. Cent., Oak Ridge Natl. Lab., Oak Ridge, Tenn.

Oceanographic Data Facility (1992a), South Atlantic Ventilation Experiment (SAVE), legs 4-5, Chem. Phys. CTD Data Rep. 92-10, 625 pp., Scripps Inst. of Oceanogr., La Jolla, Calif.

Oceanographic Data Facility (1992b), Hydros leg 4, Chem. Phys. CTD Data Rep. 92-12, 190 pp., Scripps Inst. of Oceanogr., La Jolla, Calif.

Oeschger, H., U. Siegenthaler, U. Schotterer, and A. Gugelmann (1975), A box diffusion model to study the carbon dioxide exchange in nature, Tellus, 27(2), 168-192, doi:10.1111/j.2153-3490.1975.tb01671.x.

Orr, J. C., R. Najjar, C. L. Sabine, and F. Joos (1999), Abiotic-HOWTO, internal report, 25 pp., Lab. des Sci. du Clim. et l'Environ., Gif-surYvette, France.

Peacock, S. (2004), Debate over the ocean bomb radiocarbon sink: Closing the gap, Global Biogeochem. Cycles, 18, GB2022, doi:10.1029/ 2003GB002211.

Povinec, P. P., T. Aramaki, G. S. Burr, A. J. T. Jull, L. L. W. Kwong, and O. Togawa (2004), Radiocarbon in the water column of the southwestern Pacific Ocean-24 years after GEOSECS, Radiocarbon, 46(2), 583-594.

Rafter, T. A., and G. J. Fergusson (1957), "Atom bomb effect"-Recent increase of carbon-14 content of the atmosphere and biosphere, Science, 126(3273), 557-558, doi:10.1126/science.126.3273.557.

Ribbe, J., and M. Tomczak (1997), On the effect of the missing Indonesian throughflow in the Fine Resolution Antarctic Model (FRAM), J. Phys. Oceanogr., 27, 445-455, doi:10.1175/1520-0485(1997)027<0445:EOT$\mathrm{MIT}>2.0 . \mathrm{CO} ; 2$.

Rodgers, K. B., et al. (2011), Interhemispheric gradient of atmospheric radiocarbon reveals natural variability of Southern Ocean winds, Clim. Past, 7, 1123-1138, doi:10.5194/cp-7-1123-2011.
Rubin, S. I., and R. M. Key (2002), Separating natural and bombproduced radiocarbon in the ocean: The potential alkalinity method, Global Biogeochem. Cycles, 16(4), 1105, doi:10.1029/2001GB001432.

Sabine, C. L., and T. Tanhua (2010), Estimation of anthropogenic $\mathrm{CO}_{2}$ inventories in the ocean, Annu. Rev. Mar. Sci., 2, 175-198, doi:10.1146/annurev-marine-120308-080947.

Sabine, C. L., et al. (2004), The oceanic sink for anthropogenic $\mathrm{CO}_{2}$, Science, 305, 367-371, doi:10.1126/science.1097403.

Sarmiento, J. L., J. C. Orr, and U. Siegenthaler (1992), A perturbation simulation of $\mathrm{CO}_{2}$ uptake in an ocean general circulation model, J. Geophys. Res., 97, 3621-3645, doi:10.1029/91JC02849.

Sarmiento, J. L., N. Gruber, M. A. Brzezinski, and J. P. Dunne (2004), High-latitude controls of thermocline nutrients and low latitude biological productivity, Nature, 427, 56-60, doi:10.1038/nature02127.

Schmidt, A., G. S. Burr, F. W. Taylor, J. O'Malley, and J. W. Beck (2004), A semiannual radiocarbon record of a modern coral from the Solomon Islands, Nucl. Instrum. Phys. Res. B, 223-224, 420-427, doi:10.1016/j.nimb.2004.04.080.

Siegenthaler, U. (1983), Uptake of excess $\mathrm{CO}_{2}$ by an outcrop-diffusion model of the ocean, J. Geophys. Res., 88(C6), 3599-3608, doi:10.1029/ JC088iC06p03599.

Smith, R., et al. (2010), Parallel Ocean Program (POP) reference manual, Tech. Rep. LA-UR-10-01853, Los Alamos Natl. Lab., Los Alamos, N. M. Stammer, D., K. Ueyoshi, A. Köhl, W. G. Large, S. A. Josey, and C. Wunsch (2004), Estimating air-sea fluxes of heat, freshwater, and momentum through global ocean data assimilation, J. Geophys. Res., 109, C05023, doi:10.1029/2003JC002082.

Suess, H. E. (1955), Radiocarbon concentration in modern wood, Science, 122, 415-417, doi:10.1126/science.122.3166.415-a.

Sweeney, C., E. Gloor, A. R. Jacobson, R. M. Key, G. McKinley, J. L. Sarmiento, and R. Wanninkhof (2007), Constraining global air-sea gas exchange for $\mathrm{CO}_{2}$ with recent bomb ${ }^{14} \mathrm{C}$ measurements, Global Biogeochem. Cycles, 21, GB2015, doi:10.1029/2006GB002784.

Toggweiler, J. R., K. Dixon, and K. Bryan (1989a), Simulations of radiocarbon in a coarse-resolution world ocean model: 1 . Steady state prebomb distributions, J. Geophys. Res., 94(C6), 8217-8242, doi:10.1029/ JC094iC06p08217.

Toggweiler, J. R., K. Dixon, and K. Bryan (1989b), Simulations of radiocarbon in a coarse-resolution world ocean model: 2. Distributions of bomb-produced carbon 14, J. Geophys. Res., 94(C6), 8243-8264, doi:10.1029/JC094iC06p08243.

Tsunogai, S., S. Watanabe, M. Honda, and T. Aramaki (1995), North Pacific intermediate water studied chiefly with radiocarbon, J. Oceanogr., 51, 519-536, doi:10.1007/BF02270522.

Vázquez-Rodríguez, M., et al. (2009), Anthropogenic carbon distributions in the Atlantic Ocean: Data-based estimates from the Arctic to the Antarctic, Biogeosciences, 6, 439-451, doi:10.5194/bg-6-439-2009.

von Reden, K. F., et al. (1999), High-precision measurements of ${ }^{14} \mathrm{C}$ as a circulation tracer in the Pacific, Indian, and Southern Oceans with accelerator mass spectrometry (AMS), AIP Conf. Proc., 473, 410-421, doi:10.1063/1.58989.

Wang, S., J. K. Moore, F. W. Primeau, and S. Khatiwala (2012), Simulation of anthropogenic $\mathrm{CO}_{2}$ uptake in the CCSM3.1 ocean circulation-biogeochemical model: Comparison with data-based estimates, Biogeosciences, 9, 1321-1336, doi:10.5194/bg-9-1321-2012.

Wanninkhof, R. (1992), Relationship between wind speed and gas exchange over the ocean, J. Geophys. Res., 97(C5), 7373-7382, doi:10.1029/92JC00188.

Watanabe, Y. W., T. Ono, K. Harada, and M. Fukasawa (1999), A preliminary study of oceanic bomb radiocarbon inventory in the North Pacific during the last two decades, J. Oceanogr., 55, 705-716, doi:10.1023/ A:1007868213682.

Waugh, D. W., T. M. Hall, B. I. McNeil, R. Key, and R. J. Matear (2006), Anthropogenic $\mathrm{CO}_{2}$ in the oceans estimated using transit-time distributions, Tellus, Ser. B, 58, 376-390, doi:10.1111/j.1600-0889.2006.00222.x.

Whitney, F. A., H. J. Freeland, and M. Robert (2007), Persistently declining oxygen levels in the interior waters of the eastern subarctic Pacific, Prog. Oceanogr., 75(2), 179-199, doi:10.1016/j.pocean.2007.08.007.

Wunsch, C., and P. Heimbach (2007), Practical global oceanic state estimation, Physica D, 230, 197-208, doi:10.1016/j.physd.2006.09.040.

Yool, A., A. Oschlies, A. J. G. Nurser, and N. Gruber (2010), A modelbased assessment of the TrOCA approach for estimating anthropogenic carbon in the ocean, Biogeosciences, 7, 723-751, doi:10.5194/bg-7723-2010. 